Hydrol. Earth Syst. Sci. Discuss., https://doi.org/10.5194/hess-2017-251

Manuscript under review for journal Hydrol. Earth Syst. Sci.

Discussion started: 6 June 2017

\title{
SWAT-CUP for Calibration of Spatially Distributed Hydrological Processes and Ecosystem Services in a Vietnamese River Basin Using Remote Sensing
}

Lan T. Ha ${ }^{1,2}$, Wim G.M. Bastiaanssen ${ }^{1,3}$, Ann van Griensven ${ }^{3,4}$, Albert I.J.M. van Dijk ${ }^{5,6}$ and Gabriel B. 5 Senay $^{7}$

${ }^{1}$ Delft University of Technology, 2628 CN Delft, The Netherlands

${ }^{2}$ Institute of Water Resources Planning, Hanoi, Vietnam

${ }^{3}$ IHE Delft Institute for Water Education, 2611 AX Delft, The Netherlands

${ }^{4}$ Vrije Universiteit Brussel, Brussel, 1050, Belgium

$10 \quad{ }^{5}$ Fenner School of Environment \& Society, Australian National University, Canberra, ACT 2601, Australia

${ }^{6}$ Commonwealth Scientific and Industrial Research Organisation (CSIRO), Canberra, ACT 2601, Australia

${ }^{7}$ U.S. Geological Survey Earth Resources Observation Science Center, North Central Climate Science Center, Fort Collins, Colorado, CO 80526, USA

Correspondence to: Lan Thanh Ha (t.1.ha-2@tudelft.nl)

15 Abstract

Distributed hydrological models are usually calibrated against the measured outflow of a certain drainage area, provided flow data is available. A close match with flow does however not mean that the spatially distributed hydrological processes are properly understood and simulated. In this paper, remotely sensed precipitation, evapotranspiration (ET) and leaf area index (LAI) from open access data sources were used to calibrate the SWAT model for the Day Basin, a tributary of the Red River in Vietnam. The efficacy of the SWAT-CUP parameter sensitivity and optimization model developed by Abbaspour (2015) was tested with spatial remote sensing input parameters. The innovation is that the parameters of the soil-vegetation processes were optimized for every Hydrological Response Unit for which remotely sensed monthly ET and LAI values were available. Such level of detail cannot be achieved from flow measurements, which are the integrated result of many processes over large areas. A total of 15 soil-vegetation process parameters were calibrated. The SUFI2 algorithm in SWAT-CUP appeared to be an adequate practical tool for the calibration process. Simulated monthly ET correlations with remote sensing estimates showed an $\mathrm{R}^{2}=0.71$ and NSE $=0.65$ while monthly LAI showed correlations of $\mathrm{R}^{2}=0.59$ and $\mathrm{NSE}=0.57$ over a five year validation period. Accumulated modelled ET over the 5-year calibration period amounted to $5713 \mathrm{~mm}$ compared to $6015 \mathrm{~mm}$ of remotely sensed ET: a non-significant difference of $302 \mathrm{~mm}$ (5.3\%). Because river flow was not optimized during the calibration process, it could be used as an independent validation of the calibrated model simulations. The monthly flow at two flow measurement stations were adequately estimated $\left(\mathrm{R}^{2}=0.78\right.$ and 0.55 , NSE $=0.71$ and 0.63 for Phu Ly and Ninh Binh, respectively). The estimated total water withdrawal from the Red River was 1.934 billion $\mathrm{m}^{3} / \mathrm{yr}$ with a peak flow of approximately $200 \mathrm{~m}^{3} / \mathrm{s}$ during the months of February and July. 
Hydrol. Earth Syst. Sci. Discuss., https://doi.org/10.5194/hess-2017-251

Manuscript under review for journal Hydrol. Earth Syst. Sci.

Discussion started: 6 June 2017

(c) Author(s) 2017. CC BY 3.0 License.

The availability of a reliable set of parameters will make SWAT a useful tool for optimizing water conservation, agricultural outputs, and ecosystem services such as reduced soil erosion, better water quality standards, carbon sequestration, micro-climate cooling amongst others. Such calibrated distributed eco-hydrological models can be used for appraising scenarios of green growth.

\section{Introduction}

Managing river basins and environmental systems in a sustainable manner is receiving growing attention from national water resources institutes, the United Nations, non-governmental-organizations and international research institutes. The newly adopted Sustainable Development Goals (SDGs) prescribe key hydrological, environmental and economical processes to be expressed in terms of performance indicators. Water accounting systems are currently under development to facilitate the mapping and description of these SDG indicators at river basin scale (e.g. Molden, 1997; Vardon et al., 2007; Droogers et al., 2010; Karimi et al., 2013). Water availability, water consumption, utilizable water and water withdrawals are key elements of such accounting processes, as well as the services and benefits rendered. At the global scale, $60 \%$ of ET is from green water (precipitation stored in soil moisture), the rest being withdrawals from blue water sources (rivers, reservoirs, lakes, and aquifers); see Molden et al. (2007). Eco-hydrological modelling tools have been developed to quantify a wide range of natural

15 as well as human intervention ecosystem services derived from these significant volumes of water (Crossman et al., 2013; Bagstad et al., 2013). Vigorstol and Aukema (2011) compared different hydrological models that are suitable for modelling hydrological ecosystem services. Among them are the Soil Water Assessment Tool (SWAT) (Arnold et al., 1998), Variable Infiltration Capacity VIC (Liang et al., 1994), INVEST (Tallis and Polaski, 2009) and ARtificial Intelligence for Ecosystem Services ARIES (Villa et al., 2009). Francescioni et al. (2016) conducted a rigorous review of the modelling of certain

20 ecosystem services and indicated that SWAT is preferable for the simulation of provisioning and regulating services, because hydrological, flow dynamics, water quality, plant growth and nutrient loading processes are included in the model. SWAT was also recommended by Dechmi et al., (2012) as the most suitable model for long-term simulations in watersheds dominated by agricultural land uses, since its original design was to assess the impact of land management practices on water, sediments and agricultural residues. The SWAT model is preferred in studies related to ungauged basins as indicated by Gitau and Chaubey, 2010 and Srinivasan, 2010.

Classically, the SWAT model is calibrated using a few hydro-meteorological stations (e.g. Schneider et al., 2007; van Griensven et al., 2012; Shrestha et al., 2013; Abbaspour et al., 2015). Bitew and Gebremichael (2011) indicated that large uncertainties in observed stream flow data are common and that more sophisticated calibration methods needed to be developed. SWAT-CUP (Abbaspour, 2015) was developed for automatically computing sensitive model parameters and calibrate SWAT by means of parameter optimization. SWAT-CUP offers a few alternative calibration methodologies and allows the user to run the procedure many times until convergence is reached. It is designed and applied to field measurements 
Hydrol. Earth Syst. Sci. Discuss., https://doi.org/10.5194/hess-2017-251

only. As far as the authors are aware, SWAT-CUP has not yet been applied with remote sensing data. The current paper investigates how SWAT can be set up for assessing ecosystem services in ungauged basins using remote sensing data.

Several review papers on remote sensing technology for hydrology (e.g. Pietroniro and Leconte, 2000; Neale and Cosh, 2010;)

5 and water management (e.g. Bastiaanssen and Harshadeep, 2005; Melesse et al., 2007 ) indicate that land cover, land use, precipitation, ET, soil moisture, snow cover and water levels can be determined from spectral radiances measured remotely. Several open-access data bases on precipitation have recently been developed on the basis of remote sensing data; see SerratCapdevilla et al. (2014). A simultaneous development took place on operationalizing remote sensing based energy balance models to accurately determine and upscale ET from local heterogeneous watersheds (Templeton et al., 2014) to continental

10 scale (Wang Erlandsson et al., 2016). Extensive reviews of remote sensing-based approaches to derive ET were carried out earlier by Li et al. (2009), Kalma et al. (2008), Senay et al. (2011) and Karimi and Bastiaanssen (2013). Carlson and Ripley (2007) showed methodologies to determine Leaf Area Index (LAI) from remote sensing data. In this Vietnamese case study, remotely sensed precipitation, ET and LAI data sets were used to improve SWAT modelling performance. Future studies should also include soil moisture, net primary production and water quality estimates, based on remote sensing data.

15

Some hydrological studies utilize remote sensing data already - or a combination of remote sensing and in situ data - to calibrate hydrological models (e.g. Droogers and Bastiaanssen, 2002; Schuurmans et al., 2003; Vazefedoust et al., 2007; Jhorar et al., 2011; Githui et al., 2012; Simons et al., 2016). Earlier research demonstrated the capacity to calibrate SWAT with remotely sensed ET data (e.g. Immerzeel and Droogers, 2008; Immerzeel et al., 2008; Cheema et al., 2013; Sun et al., 2013; Souza et

20 al., 2015) and LAI (Bréda, 2003, van Griensven et al., 2012b). Several studies in Vietnam integrated SWAT and remote sensing data. Raghavan et al. (2014) for instance studied the impact of climate change on stream flow in Dakbla River Basin. The objective of this paper is to test SWAT-CUP with quasi open access remote sensing measurements. The innovation is that the standard calibration module is based on remote sensing data instead of classical discharge data and that it incorporates soil and vegetation parameters of individual HRU units. The anticipated result of such a calibration approach is a better quantification of the natural and anthropogenic eco-hydrological processes in un-gauged basins, which is vital for reporting ecosystem services to governments and the United Nations.

\section{Study area}

The Day Basin is located between $19^{\circ} 55^{\prime}$ to $21^{\circ} 10^{\prime} \mathrm{N}$ and $105^{\circ} 20^{\prime}$ to $106^{\circ} 25^{\prime} \mathrm{E}$. The Day Basin is a sub-basin of the transboundary Red River basin (See Fig. 1). The total area of the basin is nearly $6300 \mathrm{~km}^{2}$. The highest elevation is $1256 \mathrm{~m}$ in

30 the western part of the basin. The magnified background in Fig. 1b is the Shuttle Radar Topography Mission (SRTM) Digital Elevation Model with a 1 arc-second resolution. The Day Basin comprises several river tributaries among which the largest is the Day River with a total length of approximately $250 \mathrm{~km}$. The Day Basin has a high biodiversity with abundant flora and 
Hydrol. Earth Syst. Sci. Discuss., https://doi.org/10.5194/hess-2017-251

Manuscript under review for journal Hydrol. Earth Syst. Sci.

Discussion started: 6 June 2017

(c) Author(s) 2017. CC BY 3.0 License.
Hydrology and

Earth System

Sciences

Discussions

(c) $\underset{\mathrm{BY}}{(i)}$

fauna in the forested hills, freshwater aquatics and wetland. The land use is also diversified, although agricultural land use is dominant $(64 \%)$.

The Day Basin encompasses the capital city of Hanoi (population in 2015: 7.5 million inhabitants) in the northeast and several

5 major economic centers located downstream, such as Nam Dinh (population: 1.8 million) and Ninh Binh (population: 0.9 million). Both the Red River and Day Basin have been exposed to various hydrological research activities before (e.g. Luu et al., 2010; Le et al., 2005; Simons et al., 2016; Giuliani et al., 2016). Water levels are measured daily in two locations Ninh Binh and Phu Ly (Fig.1b) and are available from the year 2000 up to 2013. The daily flow rate was calculated from daily mean water levels using the Q (h) relationship established by Luu et al. (2009). The discharges in several cross sections were

10 measured using an Acoustic Doppler Current Profilers (Mueller and Wagner, 2009). The correlation between discharges and water levels were found acceptable with a coefficient of determination $\mathrm{R}^{2}$ ranging from 0.83 (Phu Ly) to 0.86 (Ninh Binh). The flow rates in the main river course will be used to verify the surface runoff and baseflow computations of SWAT.

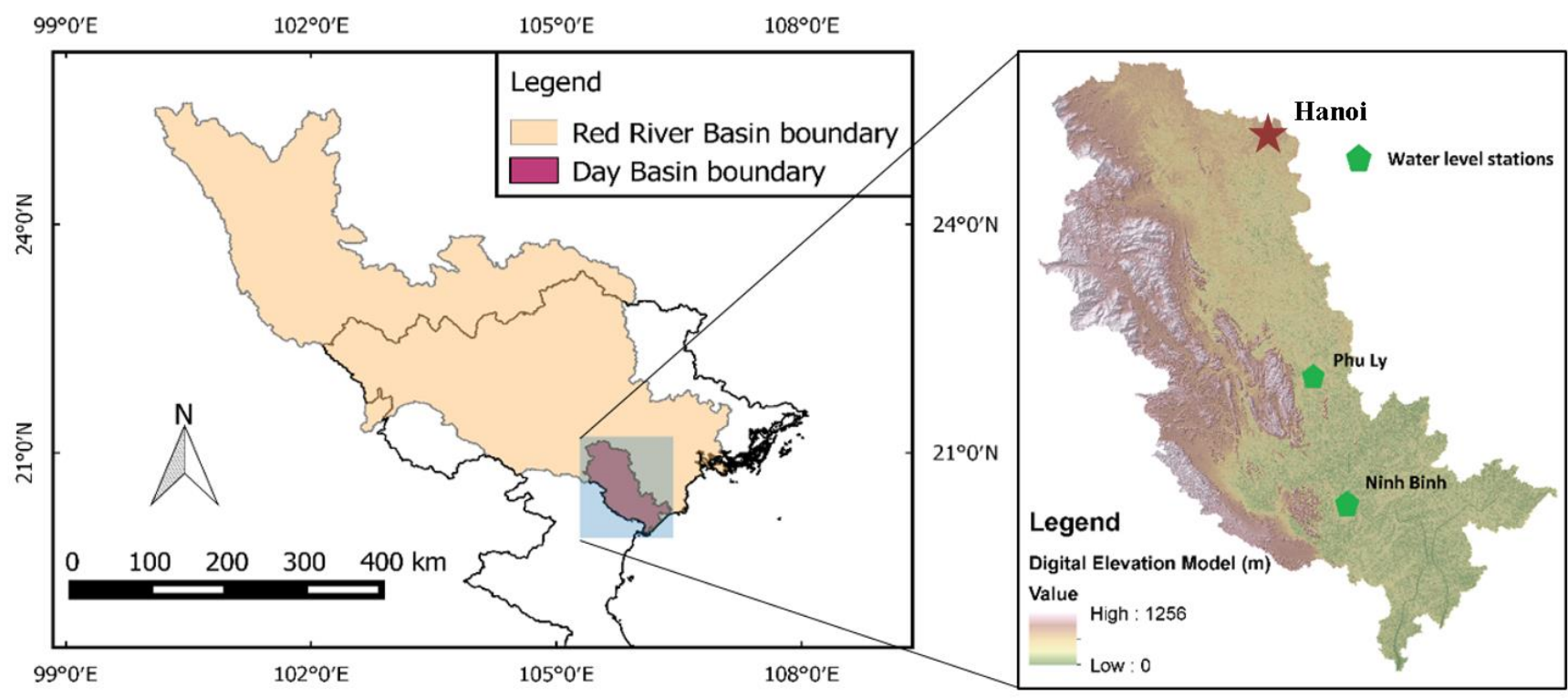

a) Overview of the Day River Basin

b) Day River Basin

15 Figure 1: a) Geographical location of the Day Basin as part of the Red River delta in Northern Vietnam. b) Digital Elevation Model from SRTM for the Day River Basin and the location of two water level stations

The annual total precipitation is around $1700 \mathrm{~mm} / \mathrm{yr}$ and reference evapotranspiration $\left(\mathrm{ET}_{\mathrm{o}}\right.$ ) is approximately $1100 \mathrm{~mm} / \mathrm{yr}$. The climate in the Day Basin has a monsoonal character. The wet season lasts from May to September and dry season from October to April. Precipitation can reach up to $450 \mathrm{~mm}$ per month in some parts of the basin, and as low as a few mm during

20 January and February (Fig. 2). Precipitation is measured at nine stations across the basin and is available up to 2013. These measurements will be used to validate the open access precipitation product based on satellite measurements. 
Hydrol. Earth Syst. Sci. Discuss., https://doi.org/10.5194/hess-2017-251

Manuscript under review for journal Hydrol. Earth Syst. Sci.

Discussion started: 6 June 2017

(c) Author(s) 2017. CC BY 3.0 License.
Hydrology and

Earth System

Sciences

Discussions

(c) (i)

The meteorological data set includes daily estimates of solar radiation, wind speed, air temperature (maximum, minimum) and relative humidity. The data set was derived from the Global Land Data Assimilation System (GLDAS). GLDAS simulates meteorological data with a numerical weather prediction model having a cell size of 0.25 degrees. The NOAH land surface model coupled to an atmospheric boundary layer model assimilates satellite and in situ measurements to produce various land surface states and fluxes (Rodell et al., 2004). In this study, 3-hourly meteorological data was downloaded and integrated into daily time step.

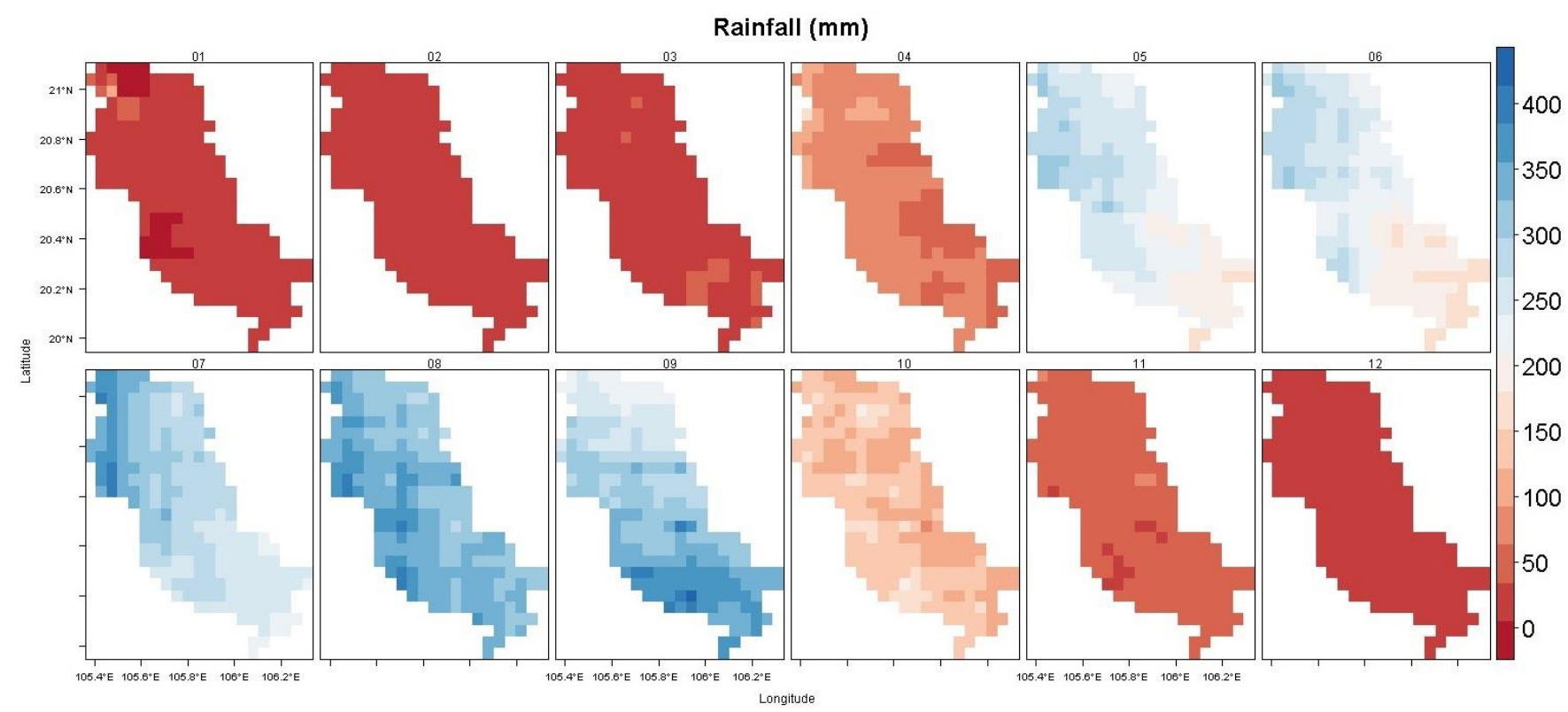

Figure 2: Monthly average precipitation for the Day Basin using CHIRPS the precipitation product (methodology was detailed in Section 3.1.1)

10 The irrigation water withdrawals for irrigated rice in the Day Basin are rather difficult to assess because various pumping stations lift water from the Red river, and also many upstream inlets divert water from the Red river gravitationally. This diffusive and unmetered water withdrawals complicates the computation of the irrigation hydrology and the water accounts related to that. However, by optimizing the ET values in SWAT-CUP, estimates of withdrawals can be made realistically.

\section{Model and Methodology}

\section{3.1 Soil and Water Assessment Tool (SWAT)}

The Soil and Water Assessment Tool (SWAT) developed by Arnold et al. (1998) and Neitsch et al. (2009) has been set up for the Day Basin to compute flow, fluxes and stocks. A total amount of 109 sub-basins and 7909 Hydrological Response Units (HRU) have been included for ensuring sufficient detail. HRU is a modeling unit which is a unique combination of land slope, land use and soil type (Arnold et al., 2012). The core engine of SWAT allows the simulation of the eco-hydrological processes, 
Hydrol. Earth Syst. Sci. Discuss., https://doi.org/10.5194/hess-2017-251

Manuscript under review for journal Hydrol. Earth Syst. Sci.

Discussion started: 6 June 2017

Hydrology and

Earth System

(c) Author(s) 2017. CC BY 3.0 License.

Sciences

Discussions

(c) (i)

i.e. surface runoff, groundwater recharge, baseflow, ET, erosion and storage change. The production of food, feed and timber, and the sequestration of carbon that is associated with it is also simulated. SWAT estimates the fate and transport of nutrients, sediment, pesticides, and bacteria in both land and water phases (Raj et al., 2010). This mathematical framework provides a great basis for the determination of various ecosystem services and SDG indicators. The soil water balance was conceptualized

5 in SWAT using following Eq. (1) as described in Neitsch et al., 2011:

$S W_{t}=S W_{0}+\sum_{i=1}^{t}\left(P-Q_{\text {surf }}-E_{a}-w_{\text {seep }}-Q_{g w}\right)$

In which $\mathrm{t}$ is the time (days), $\mathrm{SW}_{\mathrm{t}}$ is the final soil water content at day $\mathrm{t}\left(\mathrm{mm} \mathrm{H}_{2} \mathrm{O}\right)$; $\mathrm{SW}_{\mathrm{o}}$ is the initial soil water content, $\mathrm{P}$ is the amount of precipitation, $\mathrm{Q}_{\text {surf }}$ is the amount of surface runoff, $\mathrm{E}_{\mathrm{a}}$ is the amount of actual evapotranspiration, $\mathrm{w}_{\text {seep }}$ is the amount of percolation entering the vadose zone from the soil profile, and $\mathrm{Q}_{\mathrm{gw}}$ is the volume of streamflow originating from

10 groundwater, all measured in $\mathrm{mm} \mathrm{H}_{2} \mathrm{O}$ on day i. The reference evapotranspiration is computed with GLDAS meteorological input data that was also used for the determination of Figure 1. SWAT does not allow reading layers of ET 0 directly, and therefore meteorological records need to be specified. The equations for reference ET in SWAT are following the Penman Monteith method, as described in Neitsch et al., (2011).

\subsection{Model calibration using SWAT-CUP}

15 The calibration of a semi-distributed and physical based model such as SWAT requires various model parameters to be optimized to ensure a rigorous representation of a basin's processes, e.g. streamflow, ET, ecological change, etc. The calibration task therefore can become difficult and almost infeasible in many large-scale applications (Arnold et al., 2012). A number of auto-calibration and uncertainty analysis tools for SWAT were developed to support solving this problem and are currently available to assist the optimization process. This study is based on SWAT-CUP and its Sequential Uncertainty Fitting

20 algorithm (SUFI-2) to achieve a proper calibration. SWAT- Calibration and Uncertainty Program (SWAT-CUP) (Abbaspour et al., 1997; Abbaspour, 2015) is an auto-calibration and uncertainty analysis module program based on the SWAT engine. SWAT- CUP is a relatively advanced optimization system that can deal with a range of input parameters. The intelligence of SWAT-CUP allows model parameters to be predefined and optimized throughout the auto calibration process or manually adjusted iteratively between calibration batches. Due to this characteristic, SWAT-CUP is suitable for both new and advanced users of hydrological models, even though a good understanding of hydrologic processes and of parameter sensitivity is recommended in general terms (Arnold et al., 2012).

The SUFI-2 algorithm (Abbaspour et al., 1997) in the SWAT-CUP software package (Abbaspour, 2011) was used for model calibration, validation, sensitivity, and uncertainty analysis of the Day Basin. Among various evaluation coefficients allowed in SUFI-2, Nash-Sutcliff (NSE) was chosen for model optimization in SWAT-CUP. 
Hydrol. Earth Syst. Sci. Discuss., https://doi.org/10.5194/hess-2017-251

Manuscript under review for journal Hydrol. Earth Syst. Sci.

Discussion started: 6 June 2017

(C) Author(s) 2017. CC BY 3.0 License.
Hydrology and

Earth System

Sciences

Discussions

(c) (i)

For this particular study, a total number of 15 parameters were pre-selected according to their sensitivity to the evolution of ET and LAI. The selection of these parameters was based on detailed reviews and analyses on SWAT parameters carried out before by various authors (Gitau and Chaubey, 2010, Immerzeel and Droogers, 2012, Githui et al., 2012, Strauch and Volk, 2013).

\section{Spatial input data sets for SWAT}

\subsection{Physiographical maps}

The Digital Elevation Model (DEM) was downloaded from the Shuttle Radar Topography Mission (SRTM) 1 arc-second with a resolution of $30 \mathrm{~m}$ (Figure $1 \mathrm{~b}$ ). The DEM is used to calculate slope, slope lengths and to extract the stream network, solar angles and air temperature corrections. The land use map is downloaded from Globcover (Arinto et al., 2012). Globcover is

10 developed by the European Space Agency (ESA) and University of Louvain with a spatial resolution of $300 \mathrm{~m} x 300 \mathrm{~m}$. The satellite input data used for the classification was the MERIS sensor on the ENVISAT satellite during 2009. While this data set exists for several years, it captures the time span of the SWAT analysis very well. The major land cover in the Day Basin is agricultural land (64\%) followed by forests land $(24 \%)$ and mixed mosaic $(12 \%)$. Three thousand hectare (76 \%) of agricultural land is irrigated. The soil map used in this study originates from the International Soil Reference Information

15 Centre (ISRIC) (Hengl et al., 2014) and Food and Agricultural Organisation (FAO) Digital Soil Map of the World (FAO, 1995). The SoilGrids data base has a spatial resolution of $1 \mathrm{~km} \mathrm{x} 1 \mathrm{~km}$ and is produced during 2014. The physical properties included in the dataset are (i) soil organic carbon (g/kg), (ii) $\mathrm{pH}$ index (H2O solution) (\%), (iii) sand, silt and clay content $(\mathrm{kg} / \mathrm{kg})$, (iv) coarse fragments (volumetric) $(\%),(\mathrm{v})$ bulk density $(\mathrm{kg} / \mathrm{m} 3)$, (vi) cation-exchange capacity (fine earth fraction) $(\mathrm{cmol}+/ \mathrm{kg})$ and (vii) depth to bedrock $(\mathrm{cm})$. A new soil map was created by combining the two ISRIC and FAO soil maps with

20 the aims to both (i) increase the spatial representation and (ii) maintain the soil classification and soil properties from the FAO database. This task was accomplished by using standard unsupervised classification procedures (see Figure 3 ).
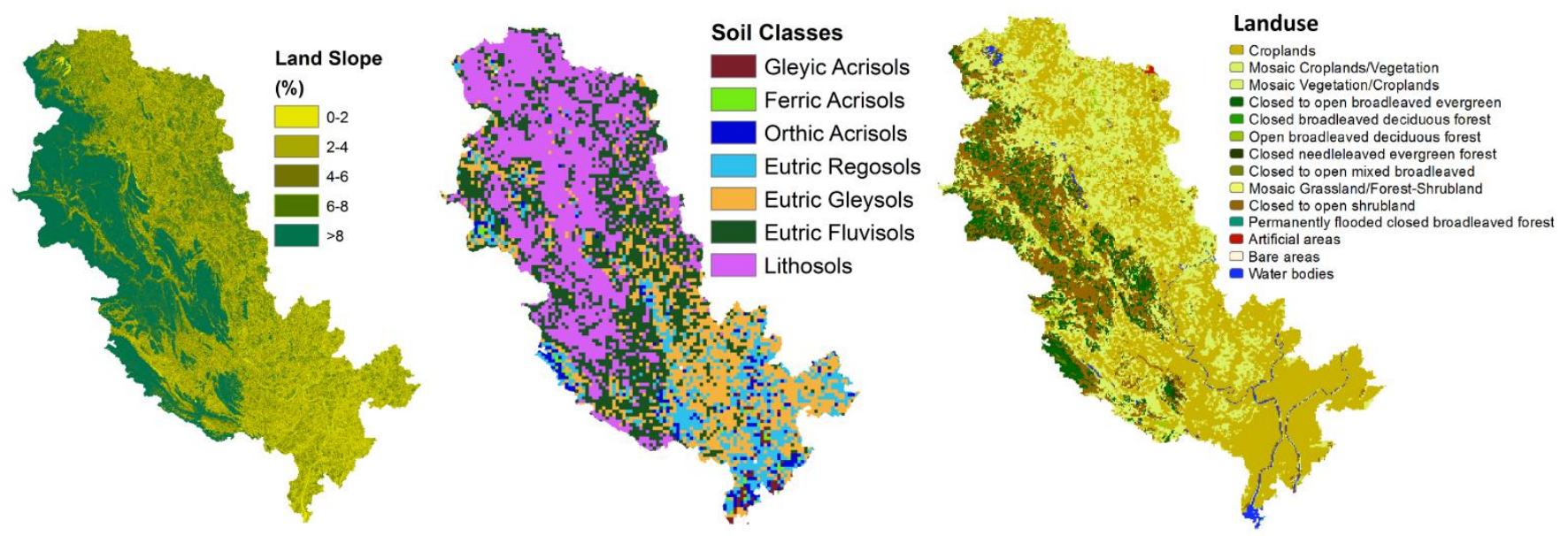
Hydrol. Earth Syst. Sci. Discuss., https://doi.org/10.5194/hess-2017-251

Manuscript under review for journal Hydrol. Earth Syst. Sci.

Discussion started: 6 June 2017

Figure 3: Land slope, soil classes and land use maps used in SWAT to determine the Hydrological Response Unit (HRU)

Based on the distribution of land slope, soil type and land use classes, the basin is divided into 119 sub-basins and 7909 HRUs.

\subsection{Meteorological data}

\subsubsection{Precipitation}

5 Satellite precipitation data offers an attractive alternative to supplement in situ precipitation measurements in hydrological modelling, particularly in poorly gauged basins (Meng et al., 2014; Serrat-Capdevilla et al., 2014). Liu et al. (2015) conducted an evaluation of various open access precipitation products such as the Tropical Rainfall Measuring Mission (TRMM 3B42V6, Climate Prediction Center Morphing technique (CMORPH), and Precipitation Estimation from Remotely Sensed Imagery Using Artificial Neural Networks (PERSIANN) at a resolution of $0.25^{\circ} \times 0.25^{\circ}$ for a subtropical watershed in China and

10 concluded that TRMM 3B42 had the best performances and deemed to be reliable for hydrological applications while PERSIANN had the worst performance. In a similar study for Southeast Asia, Peña-Arancibia et al (2012) concluded that TRMM and CMORPH performed best in this region and suggested that an ensemble precipitation product will result in a reduction of system-specific and random errors. Funk et al (2014) assimilated TRMM data, in situ measurements and other atmospheric and climatology models to create an ensemble precipitation product Climate Hazards Group InfraRed

15 Precipitation with Station data (CHIRPS) with a superior resolution at $0.05^{\circ} \times 0.05^{\circ}$. Precipitation from CHIRPS performed well statistically for flood and drought monitoring, particularly for meteorological complex regions (Toté, 2015; Simons et al., 2016).

The current study combines TRMM7.0 and CHIRPS2.0 rainfall products. The absolute precipitation data are taken from

20 TRMM and the spatial patterns from CHIRPS. The refined TRMM dataset with a resolution of $0.05^{\circ} \times 0.05^{\circ}$ so obtained has been used as input data for SWAT. The combined precipitation product so obtained showed a good performance when compared to rain gauge measurements (Fig. 4). PBIAS, NSE, MAE denoted percent bias, Nash-Sutcliffe efficiency and mean absolute error, respectively. The newly created precipitation product significantly improved the performance of the two original datasets in term of bias correction (PBIAS $=-0.6$ ) when averaging the errors from TRMM and CHIRPS. Nash-Sutcliffe

25 efficiency slightly improved when comparing the ensemble precipitation to the CHIRPS ( 0.75 compared to 0.74 ), even though the MAE was marginally larger (45.98 compared to 44.31). 
Hydrol. Earth Syst. Sci. Discuss., https://doi.org/10.5194/hess-2017-251

Manuscript under review for journal Hydrol. Earth Syst. Sci.

Discussion started: 6 June 2017

(C) Author(s) 2017. CC BY 3.0 License.

(c) (i)
Hydrology and

Earth System

Sciences

Discussions
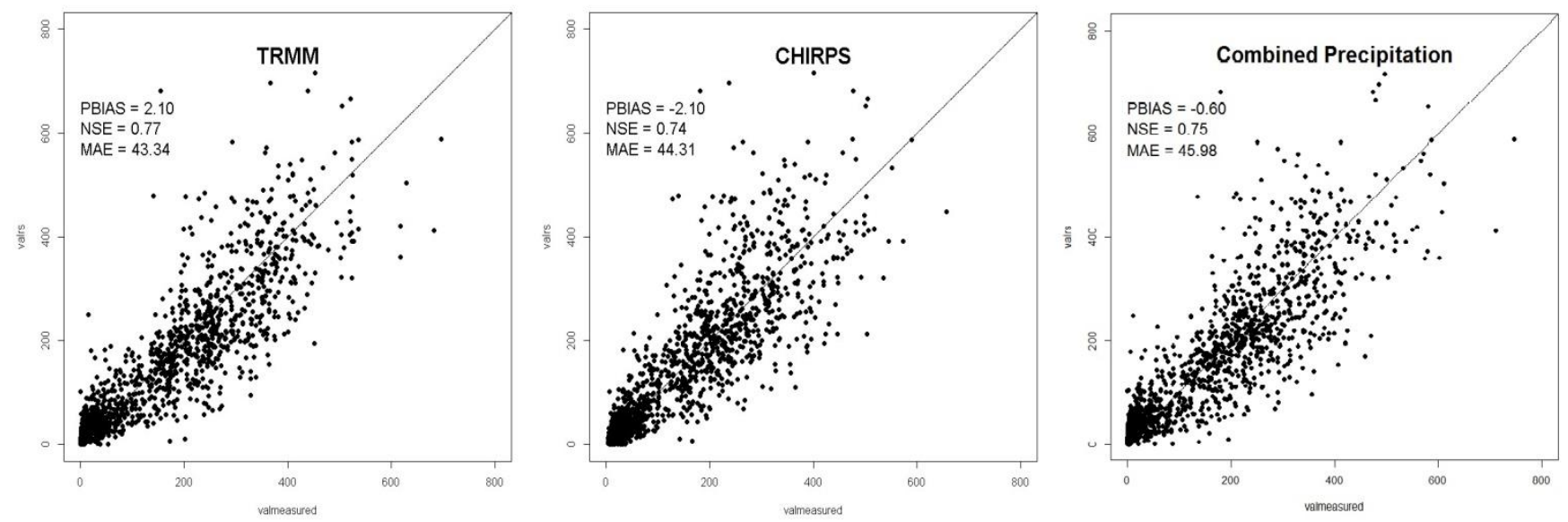

Figure 4: Performance of precipitation products TRMM, CHIRPS and the Combined Precipitation against field measurements. Remotely sensed precipitation is displayed in the vertical axes while the horizontal axes shows in situ measurement

\subsubsection{Actual evapotranspiration}

5 The most common global scale ET data set, developed with energy balance models using remote sensing data as input, is MOD16 (Mu et al., 2011). Several years of data can be downloaded if one is registered. MOD16 is based on a simplified stomatal conductance model governed by LAI, vapor pressure deficit and air temperature and a surface energy balance combination equation. Soil evaporation is limited by a complementary relationship hypothesis which defines land-atmospheric interactions from vapor pressure deficit and relative humidity (Mu et al., 2007). Various ET comparison studies, using MOD16

10 data, have been undertaken (Trambauer et al., 2014; Hu et al., 2015; Wang-Erlandsson et al., 2016). Ramoelo et al. (2014) validated MOD16 ET using flux towers in South Africa and found that ET was systematically underestimated by 7.5 to 26.3 mm per month, something confirmed by Trambauer et al. (2014) and Knipper et al. (2016). Interestingly, studies conducted in Asia showed that, despite MOD16 succeeded in establishing an overall pattern of ET mapping, there were consistent overestimates for forested land cover (Kim et al., 2011).

Another example of a global energy balance model is SEBS (Su, 2002; Chen et al., 2013). SEBS applies an analytical solution of surface roughness for heat transfer, and it was used to create a global scale data set that is quasi open access. SEBS limits the surface sensible heat flux estimates with upper and lower boundaries. The low boundary is determined by latent heat flux equal to zero and by soil moisture limitations; the upper limit by potential evapotranspiration. CMRSET (Guerschman et al.,

20 2009) calculates actual ET from the Priestley \& Taylor reference ET for water unlimited land surfaces (Priestley and Taylor, 1972 ) and a crop factor $(\mathrm{kc})$ based on an enhanced vegetation index (EVI) and global vegetation moisture index (GVMI). GVMI was applied to account for actual soil and vegetation conditions. This method is generally empirical and aims to develop an ET dataset that is independent from land cover classification. 
Hydrol. Earth Syst. Sci. Discuss., https://doi.org/10.5194/hess-2017-251

Another energy balance method is the Operational Simplified Surface Energy Balance SSEBop (Senay et al., 2013) that employs a relationship between $\mathrm{ET}_{0}$ and a land surface temperature based scalar (ETrf) to express land wetness. Senay et al. (2007) proposed an operational version of SSEB by assimilating air temperature to account for the topographical and latitudinal

5 heterogeneity impact on surface temperature. The novelty of the SSEBop model is that the difference between the hot and cold reference values is predefined for any pixel. The cold reference value is estimated as a fraction of the daily maximum air temperature; the hot reference value is obtained by adding the predefined temperature difference (dT) to the cold reference value (Senay et al., 2013).

10 Because existing global scale ET products have different predictive capabilities, and there is no reliable ground truth data set available to select any one of them, an ensemble ET product has been created on the basis of a simple linear average value for the Day Basin. The ensemble ET product used in this study is based on the combination of SEBS (5km x 5km), CMRSET $(5 \mathrm{~km} \times 5 \mathrm{~km})$, SSEBop $(1 \mathrm{~km} \times 1 \mathrm{~km})$ and MOD16 data $(1 \mathrm{~km} \times 1 \mathrm{~km})$ and has a spatial resolution of $1 \mathrm{~km} \times 1 \mathrm{~km}$ grid. A finer ET map is deemed necessary to assess water balances at HRUs spatial level. The same downscaling procedure as described in

15 CMRSET using the Enhanced Vegetation Index (EVI) and Global Vegetation Moisture Index (GVMI) was applied. The Residual Moisture Index (RMI) of Guerschman was used to describe the impact of vegetation moisture content on the crop coefficient.

The selection criteria for a certain ET product were based on the hydrological consistency between the annual totals of 20 precipitation $\left(\sum \mathrm{P}\right)$ and discharge $\left(\sum \mathrm{Q}\right)$ for a time span of 10 consecutive years. The stream flow data $(\Sigma \mathrm{Q})$ from the 2 stations (Phu Ly and Ninh Binh) were used (see Figure 5), but in the case of the Day Basin, there is an unknown inflow from the Red River, which makes a direct comparison weaker. Simons et al. (2016) used a similar approach for the Red River to select the SSEBop model that provided the best match between $\Sigma$ ET and $\sum \mathrm{P}-\sum \mathrm{Q}$, but they did not have the issue of transboundary inflow. The analysis demonstrates that SEBS produces the highest ET values and MOD16 the lowest. CMRSET and MOD16 performed similarly for annual and seasonal periods, and both were lower than mean ET. Of all five ET datasets, the ensemble ET, SSEBop and CMRSET delivered similar annual ET rates for the drainage area with flow monitored at Phu Ly ( $\Sigma E T$ of $1073 \mathrm{~mm}, 1041 \mathrm{~mm}$ and $1007 \mathrm{~mm}$ respectively) and Ninh Binh (EET of $1103 \mathrm{~mm}, 1044 \mathrm{~mm}$ and $1031 \mathrm{~mm}$, respectively). This is because the ensemble ET compensated for the difference between higher end and lower end ET products. Of all five ET datasets, SSEBop gave the most similar results compared to the ensemble ET. Albeit minor, differences were spotted

30 during the dry period. For the dry season, ET from MOD16 is comparable with the ensemble ET ( $\mathrm{EET}$ of $361 \mathrm{~mm}$ and 359 $\mathrm{mm}$ for Phu Ly, $376 \mathrm{~mm}$ and $369 \mathrm{~mm}$ for Ninh Binh, respectively) while SSEBop tends to give lower ET. 
Hydrol. Earth Syst. Sci. Discuss., https://doi.org/10.5194/hess-2017-251

Manuscript under review for journal Hydrol. Earth Syst. Sci.

Discussion started: 6 June 2017

(c) Author(s) 2017. CC BY 3.0 License.
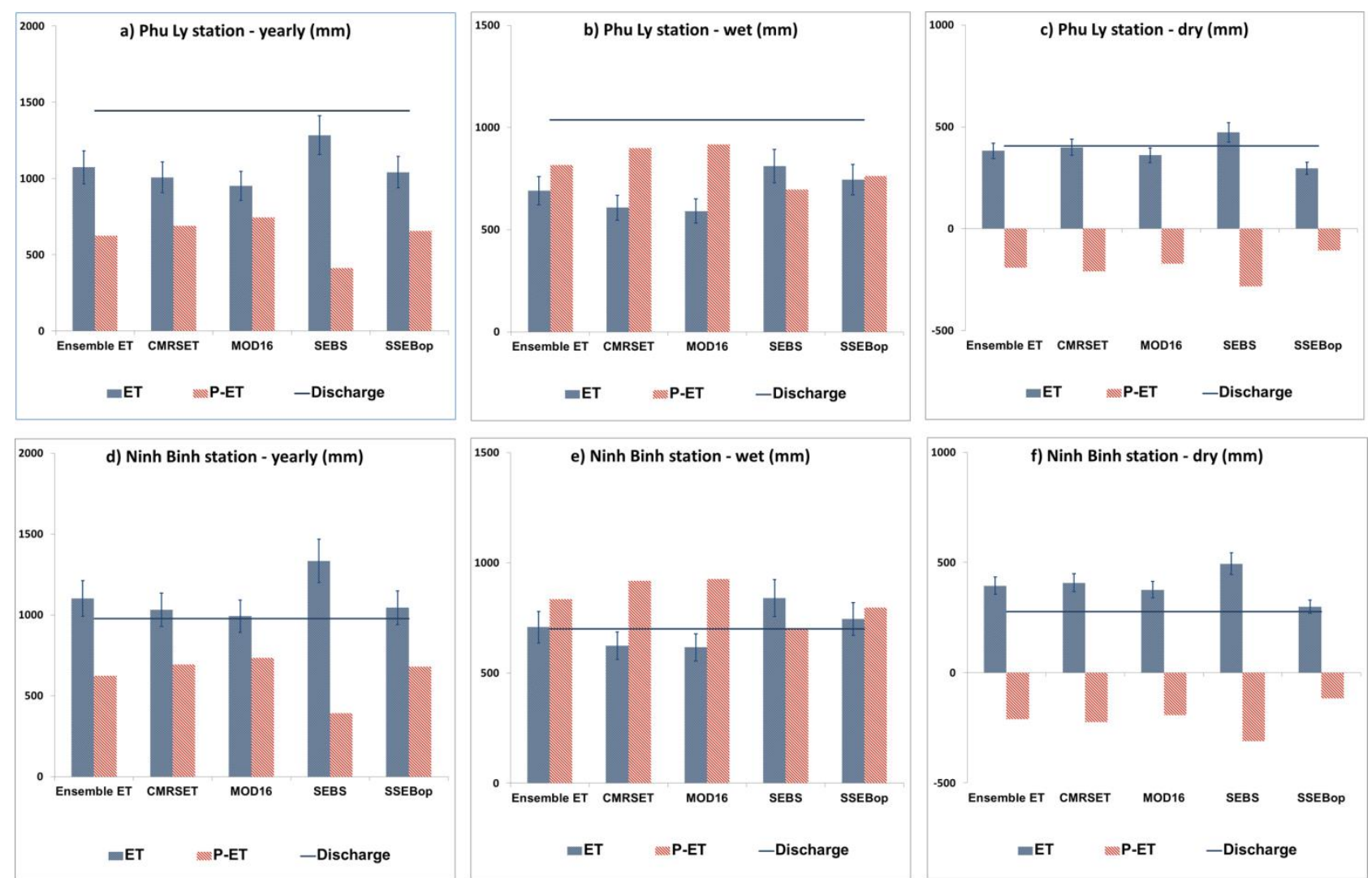

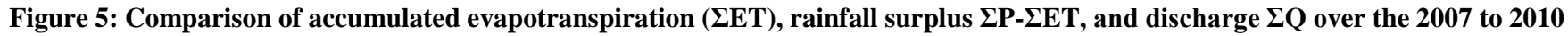
period at yearly (a,d), wet months (b,e) and dry months (c,f) at two stations Phu Ly and Ninh Binh

Figure 5 demonstrates that the longer term agreement during the wet season is good, with Phu Ly having an overestimation of

5 ET and Ninh Binh an underestimation. The latter can be related to the quality of the rating curves. The situation at annual scale is less satisfactory due to the extra inflow that is likely occurring during the dry season. This is confirmed by the dry season results in Figure 5. For this reason, the $\mathrm{R}^{2}$ and NSE values are only moderately good. Figure 6 is added to provide more insight in the monthly situation. The seasonal performance of the ensemble ET values mismatch due to storage changes in the soil water balance and the regulating role of lakes and reservoirs on river discharge. During the dry season, ET was much higher than precipitation, hence the displayed scaled differenced from the yearly average and the seasonal wet period. The interim conclusion is that the ensemble ET product generated from linear average SEBS, CMRSET, SSEBop and MOD16 provided accurate and most stable results for the Day Basin. Accordingly, the ensemble ET data was tested further before used in the SWAT-CUP optimization process. 
Hydrol. Earth Syst. Sci. Discuss., https://doi.org/10.5194/hess-2017-251

Manuscript under review for journal Hydrol. Earth Syst. Sci.

Discussion started: 6 June 2017

(c) Author(s) 2017. CC BY 3.0 License.
Hydrology and

Earth System

Sciences

Discussions

(c) (i)
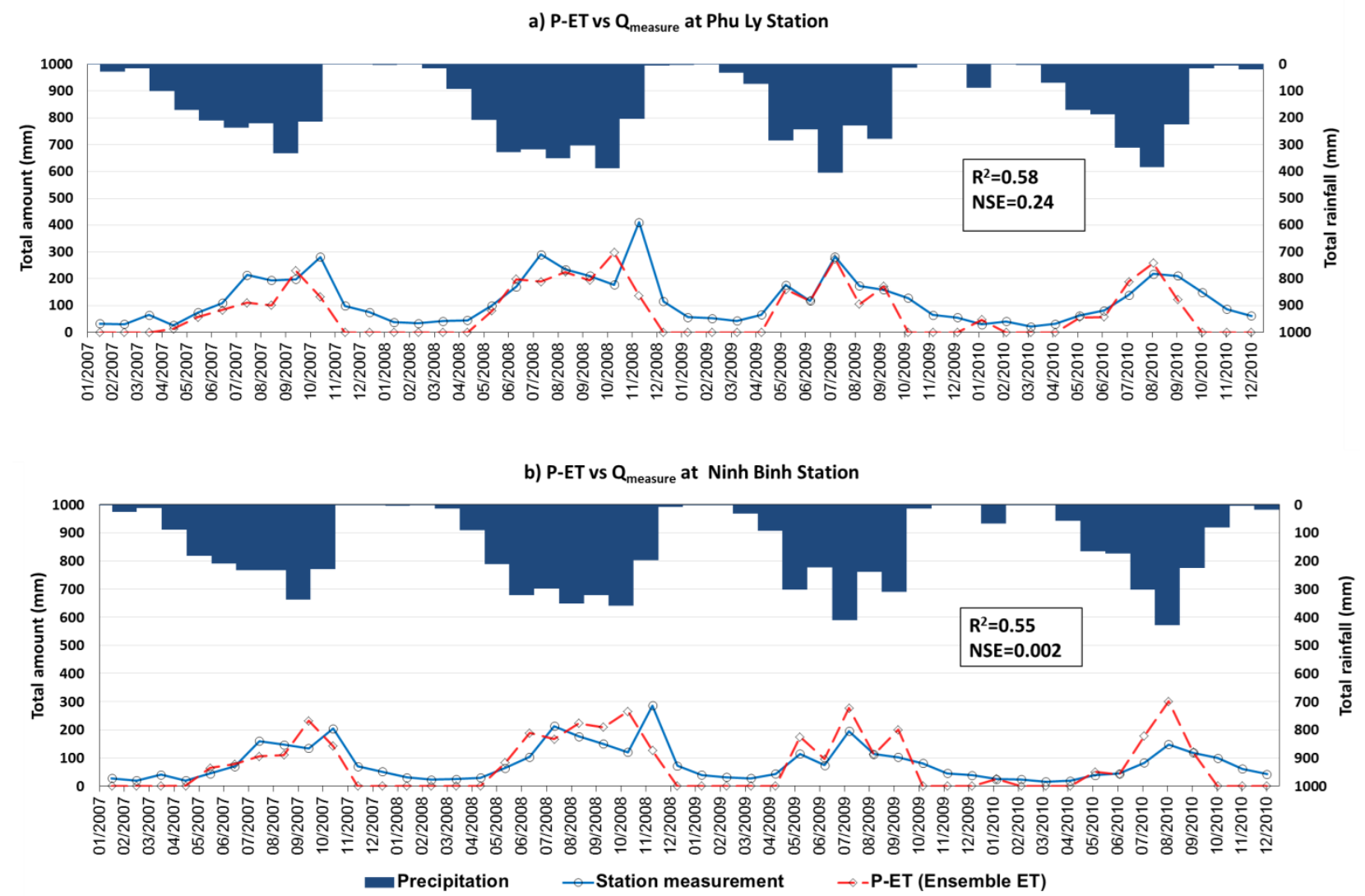

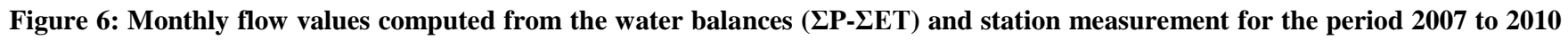
at the Phu Ly and Ninh Binh stations

\subsubsection{Crop coefficient}

5 Allen et al, (1998) defines the crop coefficient $\left(\mathrm{K}_{\mathrm{c}}\right)$ for unlimited soil water conditions, as the ratio of actual evapotranspiration to reference evapotranspiration. The Kc range for paddy rice is suggested in various studies such as by Mohan et al., 1994, Allen et al., 1998, and Vu et al., 2005. Tyagi et al. (2000) found that the Kc for rice varies between 1.02 and 1.23 throughout the growth stages. Here, we used Kc for paddy rice to examine the performance of the ensemble ET data. The Kc derived from the ensemble ET and reference ET was tested to see if it falls within the range found in the literature.

In order to validate the accuracy of actual ET derived from satellites, reference evapotranspiration (ETo) was calculated using the FAO56 Penman-Monteith equation (Allen et al., 1998) (Figure 7). GLDAS is a good example of global standardized data sets, in this case being climate related. The effect of mountains on ETo was included by considering elevation, slope and aspects following Allen et al. (2006). ETo is a good indicator of evaporative demand of the atmosphere independently of crop 
Hydrol. Earth Syst. Sci. Discuss., https://doi.org/10.5194/hess-2017-251

Manuscript under review for journal Hydrol. Earth Syst. Sci.

Discussion started: 6 June 2017

(c) Author(s) 2017. CC BY 3.0 License.

(c) (1)
Hydrology and

Earth System

Sciences

Discussions

type, crop development and management practices. ETo varies during the year and peaks during May to September, similar to the peak in precipitation. The maximum monthly ETo during this period can be over $200 \mathrm{~mm}$ (Fig. 7).

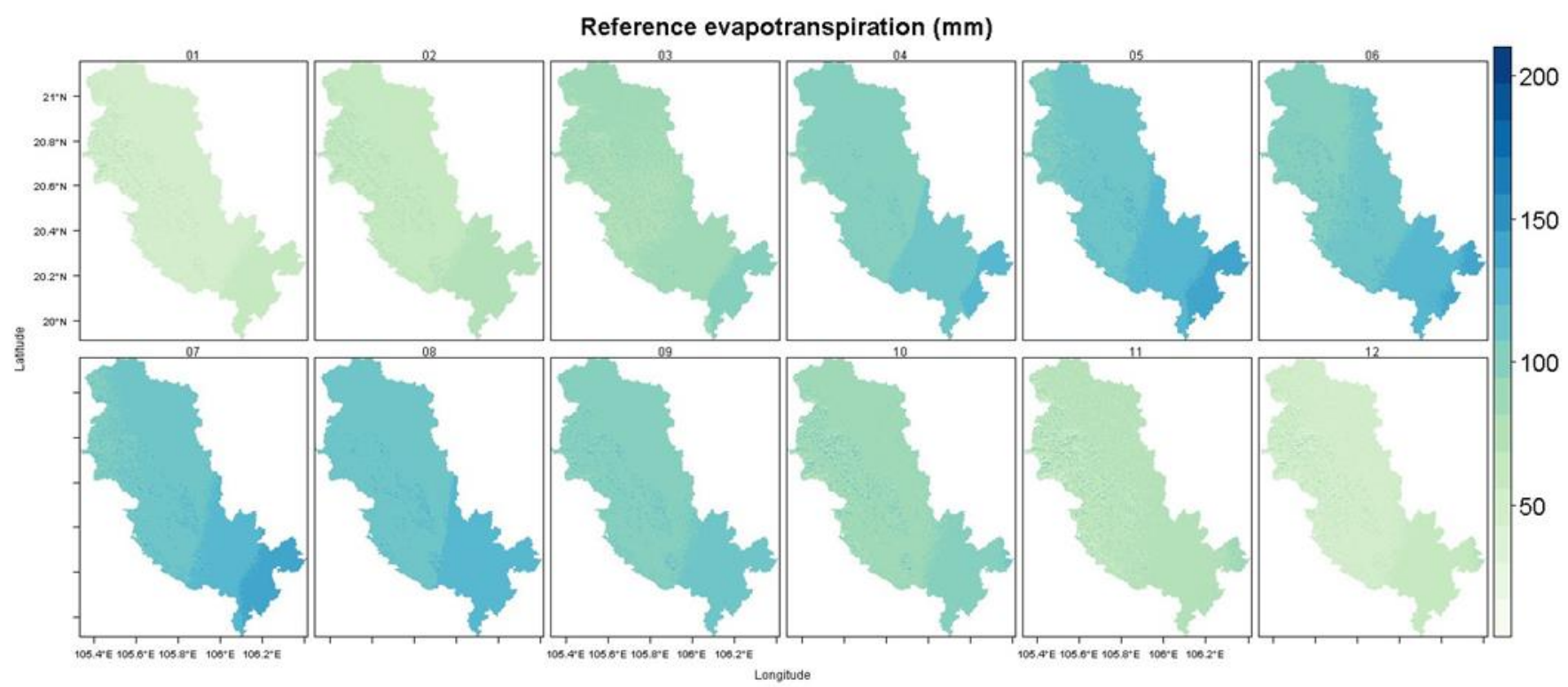

Figure 7: Monthly reference evapotranspiration rate for the Day Basin derived from GLDAS data (taken for the period 2000-2013) according to the FAO56 Penman-Monteith equation and a standard DEM from SRTM (2000)

Fig. 8 illustrates the average monthly Kc in the Day Basin. Since Kc largely depends on local climate and water management practices, maximum Kc values are experienced in the wet season (June to July). Kc is much lower in the dry months of January to February because the cropping routine is reduced. 
Hydrol. Earth Syst. Sci. Discuss., https://doi.org/10.5194/hess-2017-251

Manuscript under review for journal Hydrol. Earth Syst. Sci.

Discussion started: 6 June 2017

(c) Author(s) 2017. CC BY 3.0 License.
Hydrology and

Earth System

Sciences

Discussions

(c) $\underset{\mathrm{BY}}{(i)}$

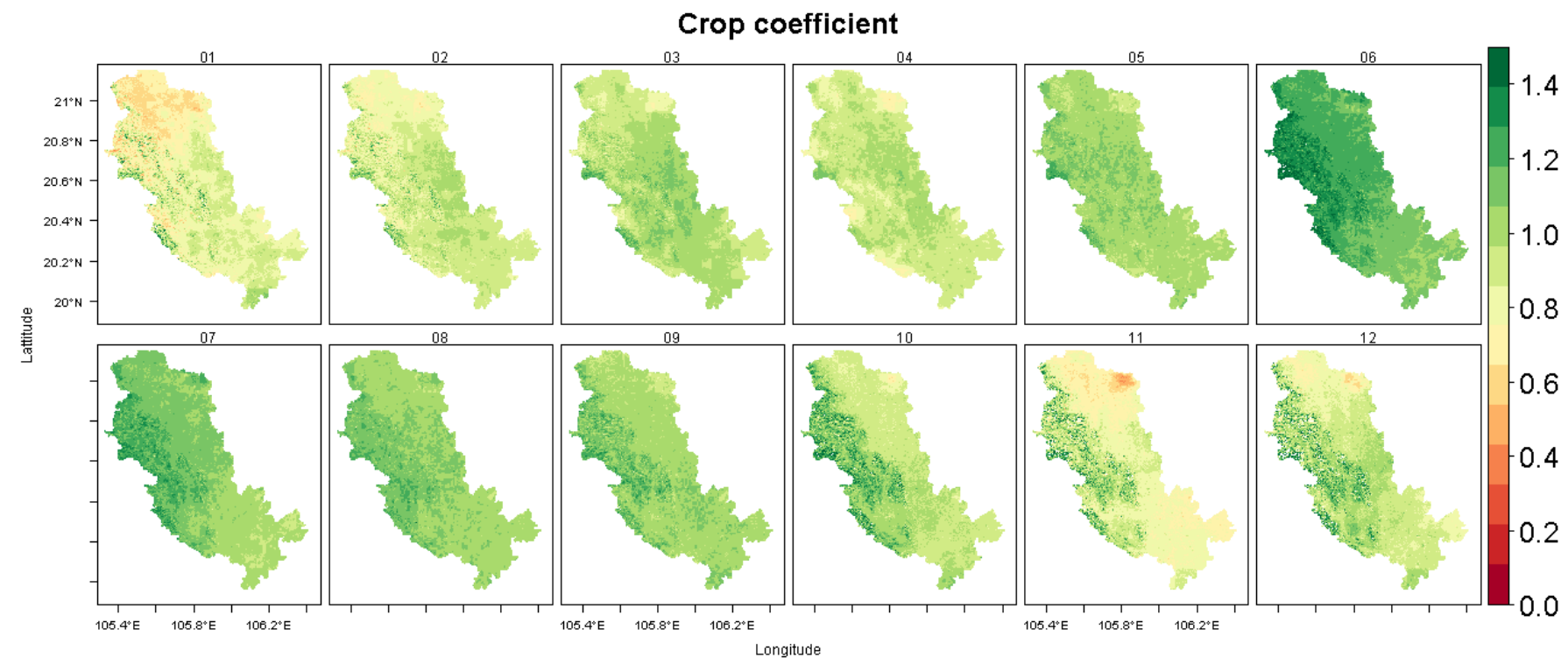

Figure 8: Monthly crop coefficient (Kc) for the Day Basin derived from the ratio between the ensemble ET and reference ET

The cropping pattern in the Day Basin consists of mainly paddy rice (2 seasons from February to April/May and from May/June to September) and other crops (vegetables, September/October to January).

5 This pattern can be seen in Fig. 9 with Kc plotted for a 3-month Simple Moving Average (SMA) from 2003 to 2010. Kc during different growing stages typically varies between 0.7 to 1.00 during the initial stages and 0.90 to 1.20 during the mid-season stage. The differences in Kc are due to the variety of cultivated paddy rice as well as irrigation management. The Kc in June to July and October to November 2008 was exceptionally high since this was a wet year. The Kc for initial growing stages varies between 0.76 to 1.00 in February (dry season rice) and 0.96 to 1.08 in May (wet season rice). This is due to the surface

10 water condition and also cultivation practices (fields were flooded earlier to transplant rice), which leads to higher ET rates compared with the dry weather condition. The mid-season Kc reached 0.81 to 1.00 and 0.96 to 1.21 in March and June respectively. These values are also similar to those of Tyagi et al. (2000) when mid-season Kc was reported to be around 1.23. The Kc during end-season (April to May for dry season rice and September for wet season rice) varies around 0.9 to 1.1, similar to crop coefficients estimated by Abdullahi et al. (2013) and Tyagi et al. (2000). 
Hydrol. Earth Syst. Sci. Discuss., https://doi.org/10.5194/hess-2017-251

Manuscript under review for journal Hydrol. Earth Syst. Sci.

Discussion started: 6 June 2017

(c) Author(s) 2017. CC BY 3.0 License.

(c) (i)
Hydrology and

Earth System

Sciences

Discussions

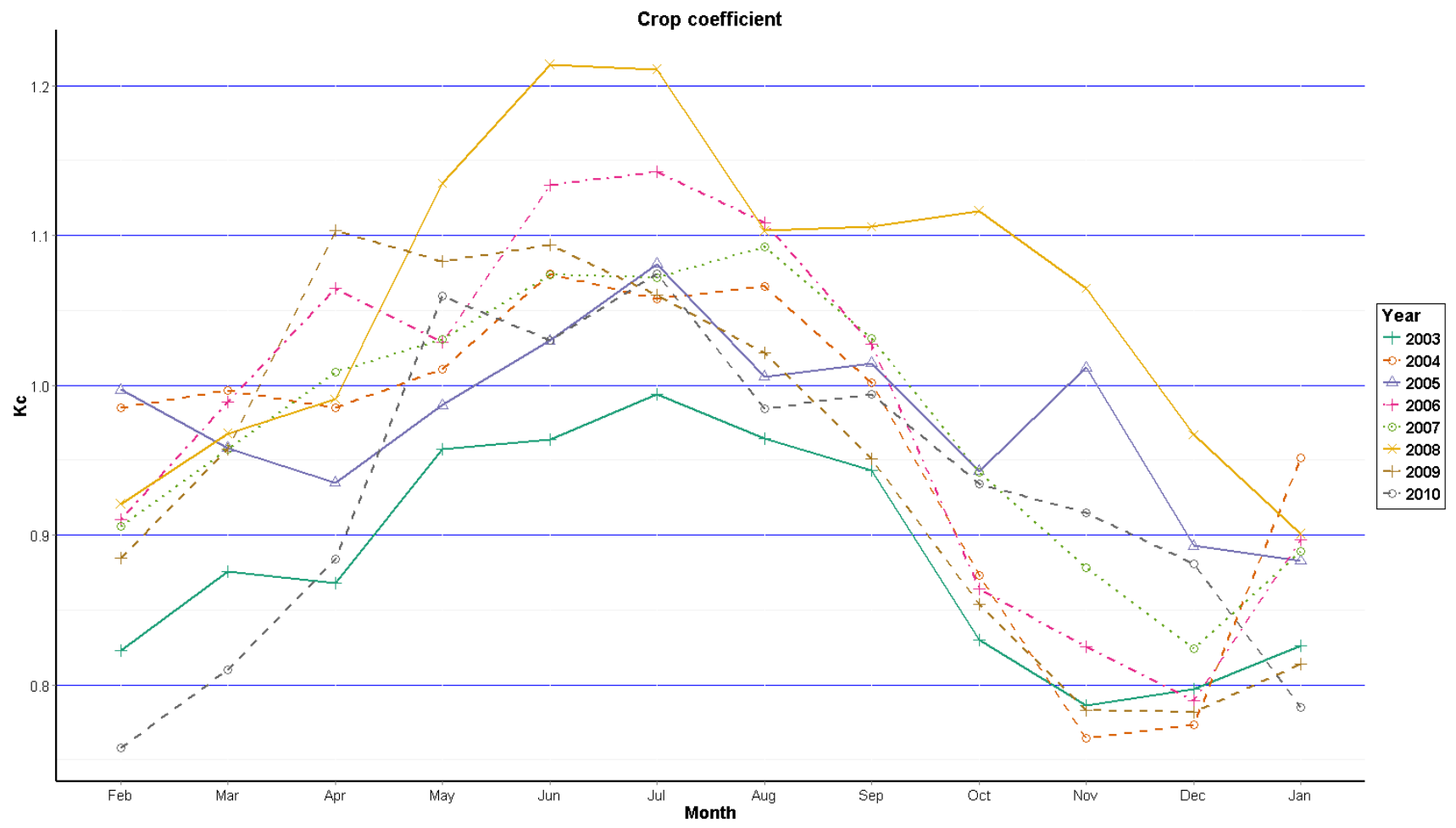

Figure 9: Simple Moving Average (SMA) for crop coefficient (Kc) for paddy rice in the Day Basin

The Kc values falling within the recommended range indicate that the ensemble ET performed well for the Day Basin and can be used for model calibration and later analyses.

\section{$5 \quad 4.3$ Leaf Area Index}

Leaf area index (LAI), defined as the area of green leaf per ground area, is an important variable for eco-hydrological modelling and quantifying ecosystem services (Parr et al., 2015; Stisen et al., 2007). LAI influences the evapotranspiration rate and its partitioning into transpiration (T) and interception (I). At the same time, LAI determines the amount of Absorbed Photosynthetically Active Radiation (APAR), which determines the energy level for photosynthesis. The SWAT model estimates LAI values assuming a certain upper boundary function of growth that is corrected for stress factors (temperature, water and nutrients). These stress factors can vary greatly and have an empirical character. The calibration of the model including LAI measurements is therefore crucial. The empirical LAI parameters to be prescribed in SWAT use an internal database. SWAT-CUP fine-tunes these parameters to ensure an accurate simulation of LAI.

15 Remote sensing provides a great source of data to study vegetation indices and LAI from multi-spectral bands based on work such as presented by Jordan (1969), Carlson and Ripley (1997) and Zheng and Moskal (2009). MODIS, VIIRS, PROBA-V, Landsat and Sentinel satellite measurements provide the means to estimate LAI with spatial resolutions of 1000, 500, 250, 100 
Hydrol. Earth Syst. Sci. Discuss., https://doi.org/10.5194/hess-2017-251

Manuscript under review for journal Hydrol. Earth Syst. Sci.

Discussion started: 6 June 2017

(c) Author(s) 2017. CC BY 3.0 License.
Hydrology and

Earth System

Sciences

Discussions

30 and $10 \mathrm{~m}$. These independently gathered LAI data can be used for the calibration of vegetation development and crop production in SWAT. MOD15-LAI data with an 8-day temporal resolution has been downloaded from which a monthly average LAI value has been reconstructed for the period of 2005-2011. The spatial resolution is $1 \mathrm{~km}$.

5 Cheema et al. (2013) for instance manually tuned the irrigation water supply until a more exact agreement on ET was achieved.

\section{SWAT parameters to be optimized}

Arnold et al. (2012) summarized various sets of parameters used in model calibration of different processes, i.e. surface runoff, snow, plant growth etc. Calibration of ET is less common because remote sensing estimates of ET are not always considered

10 as a reliable observation. More recent studies by Immerzeel and Droogers (2008), Cheema et al. (2014) and Simons et al. (2016) demonstrated that SWAT can be calibrated against ET data as well. Key parameters for the calibration of ET and their value range were derived from the SWAT user's manual (Neitsch et al., 2002) and are summarized in Table 1. Since the purpose of this study is to calibrate the model for ET and LAI, the model parameters to be optimized were divided into two groups: ET and LAI. This grouping indicates which parameters are most sensitive to ET and LAI and thus suitable for

15 optimizing the model performance for these two processes. The list is long because one parameter might control more than one process, e.g. the available water capacity of soil layers effects the generation of surface flow but also determines the amount of water that is evaporated (ET). SWAT-CUP automatically optimizes the selected parameters within their predefined range, hence this aspect of parameter selection is following the default guidelines of the tool.

20 The parameters ESCO, EPCO, REVAPMN, SOL_K, SOL_AWC and SOL_BD affect the performance of the ET simulations (Raj et al., 2010). The baseflow recession constant ALPHA_BF and SCS runoff curve number (CN2) were also included because of their influences on the surface-subsurface hydrological processes, and thus on the water availability for evapotranspiration.

25 Six parameters are identified that influence the leaf area index development, see Neitsch et al., (2009): BLAI, ALAI_MIN, LAIMX1, LAIMX2, DLAI, FRGRW1 and FRGRE2.

Table 1: Parameterization in SWAT model used for flow, ET and LAI calibration. The allowed range was defined by Arnold et al. (2012)

\begin{tabular}{|l|l|l|l|l|}
\hline Group & Parameter & Description & Range* $^{*}$ & Unit** \\
\hline ET & ESCO & Soil evaporation compensation factor & $0-1$ & - \\
\hline ET & EPCO & Plant uptake compensation factor & $0-1$ & - \\
\hline
\end{tabular}

30 Note:

*: Taken from Arnold et al. (2012) 
Hydrol. Earth Syst. Sci. Discuss., https://doi.org/10.5194/hess-2017-251

\begin{tabular}{|c|c|c|c|c|}
\hline ET & REVAPMN & $\begin{array}{l}\text { Threshold depth of water in the shallow aquifer for "revap" } \\
\text { to occur }\end{array}$ & $0-500$ & $\mathrm{~mm}$ \\
\hline ET & SOL_K & Saturated hydraulic conductivity & $0-2000$ & $\mathrm{~mm} / \mathrm{hr}$ \\
\hline ET & SOL_AWC & Available water capacity of the soil layer & $0-1$ & $\mathrm{~mm}$ water/mm soil \\
\hline ET & SOL_BD & Moist bulk density & $1.1-1.9$ & $\mathrm{mg} / \mathrm{m}^{3}$ or $\mathrm{g} / \mathrm{cm}^{3}$ \\
\hline ET & $\mathrm{CN} 2$ & SCS Curve number & $35-98$ & - \\
\hline ET & ALPHA_BF & Baseflow recession constant & $0-1$ & - \\
\hline LAI & BLAI & Maximum potential leaf area index & $0.5-10$ & $\mathrm{~m}^{2} / \mathrm{m}^{2}$ \\
\hline LAI & ALAI_MIN & Minimum lead area index for plant & $0-0.99$ & $\mathrm{~m}^{2} / \mathrm{m}^{2}$ \\
\hline LAI & DLAI & $\begin{array}{l}\text { Fraction of growing season when leaf area begins to } \\
\text { decline }\end{array}$ & $0.15-1$ & - \\
\hline LAI & LAIMX1 & $\begin{array}{l}\text { Fraction of the maximum leaf area index corresponding to } \\
\text { the } 1^{\text {st }} \text { point on the optimal leaf area development curve }\end{array}$ & $0-1$ & - \\
\hline LAI & LAIMX2 & $\begin{array}{l}\text { Fraction of the maximum leaf area index corresponding to } \\
\text { the } 2^{\text {nd }} \text { point on the optimal leaf area development curve }\end{array}$ & $0-1$ & - \\
\hline LAI & FRGRW1 & $\begin{array}{l}\text { Fraction of the plant growing season or fraction of total } \\
\text { potential hear units corresponding to the } 1^{\text {st }} \text { point on the } \\
\text { optimal leaf area development curve }\end{array}$ & $0-1$ & - \\
\hline LAI & FRGRW2 & $\begin{array}{l}\text { Fraction of the plant growing season or fraction of total } \\
\text { potential hear units corresponding to the } 2^{\text {nd }} \text { point on the } \\
\text { optimal leaf area development curve }\end{array}$ & $0-1$ & - \\
\hline
\end{tabular}

\section{Results and discussions}

The simulation covered the period 2000 to 2013 using 3 years of initialization (2000 to 2002) as modelling warm up period. Because remotely sensed data had a different temporal coverage: 2003 to 2012 for ET and 2005 to 2011 for LAI, SWAT was

5 calibrated from 2003 to 2007 for ET, and validated from 2008 to 2012. LAI was calibrated from 2005 to 2007 and validated from 2008 to 2011. The SWAT-CUP was initiated to auto-calibrate the model with over 1500 simulations divided into three batches with 500 simulations each. This number of runs was recommended by Abbaspour (2015).

Figure 10 shows, for every HRU, the distributed ET from the SWAT model and ensemble ET over the period 2003 to 2012.

10 These graphs showed good spatial agreement between the two datasets. SWAT ET was underestimated by 5-10 percent in the 
Hydrol. Earth Syst. Sci. Discuss., https://doi.org/10.5194/hess-2017-251

Manuscript under review for journal Hydrol. Earth Syst. Sci.

Discussion started: 6 June 2017

(c) Author(s) 2017. CC BY 3.0 License.

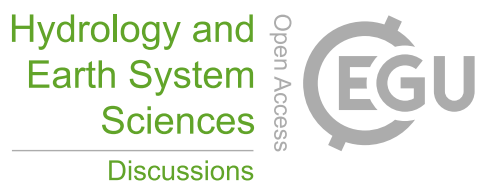

(c) (i)

irrigated agricultural land downstream while the forest land showed good correlation. The calibration yielded a NSE ranging from 0.61 for ET and 0.5 for LAI. For validation, NSE was 0.65 for ET and 0.57 for LAI. 
Hydrol. Earth Syst. Sci. Discuss., https://doi.org/10.5194/hess-2017-251

Manuscript under review for journal Hydrol. Earth Syst. Sci.

Discussion started: 6 June 2017

(c) Author(s) 2017. CC BY 3.0 License.
Hydrology and

Earth System

Sciences

Discussions

(c) (i)
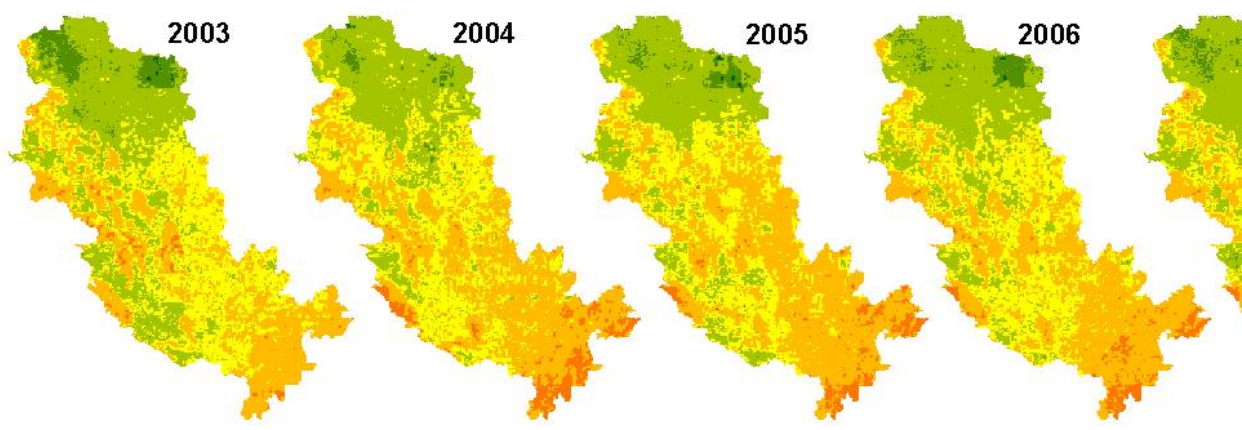

2007

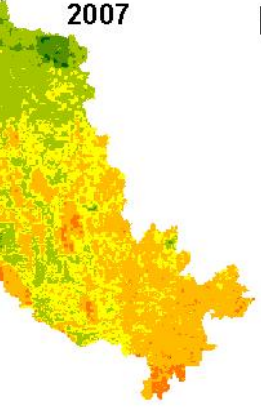

RS ET (mm)
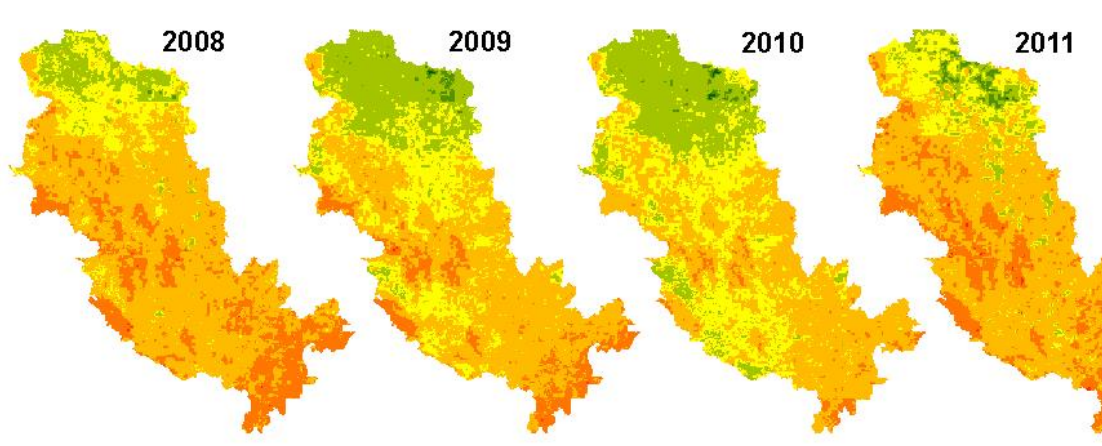

(a)
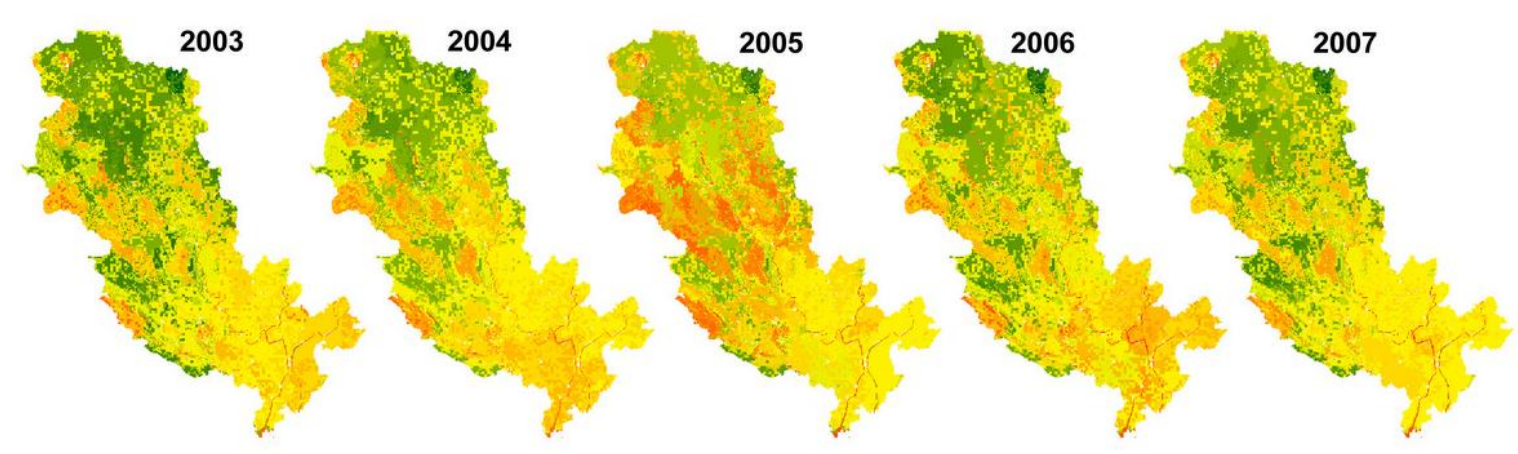

\section{Simulated ET (mm)}
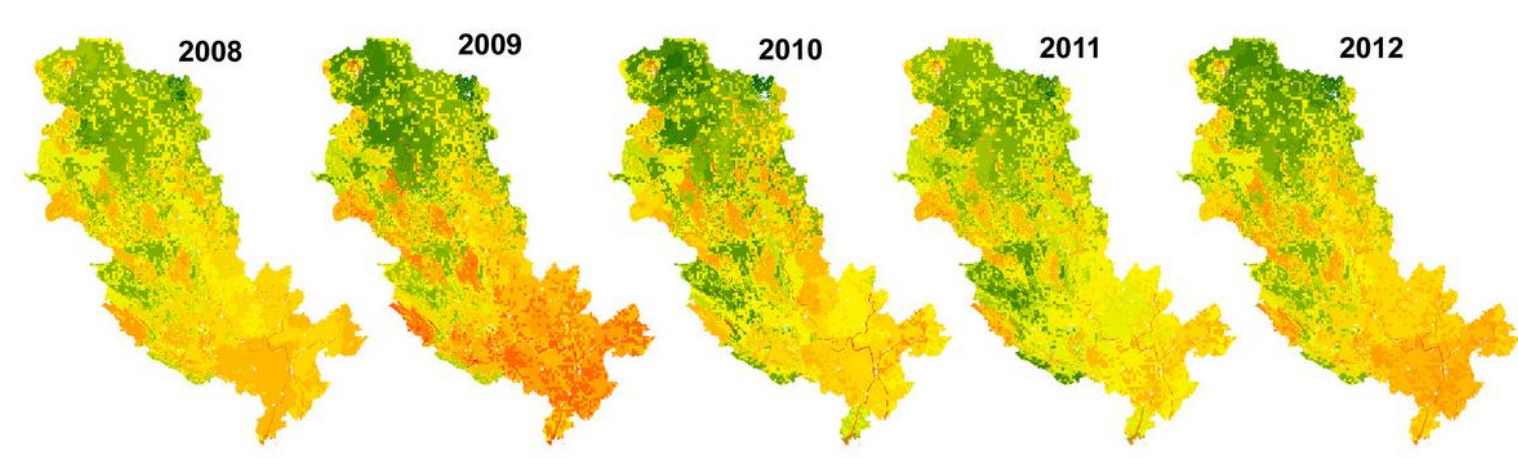

$572-600$
$600-650$
$650-700$
$700-750$
$750-800$
$800-850$
$850-900$
$900-950$
$950-1000$
$1000-1050$
$1050-1100$
$1100-1150$
$1150-1200$
$1200-1250$
$1250-1300$
$1300-1350$

(b) 
Hydrol. Earth Syst. Sci. Discuss., https://doi.org/10.5194/hess-2017-251

Manuscript under review for journal Hydrol. Earth Syst. Sci.

Discussion started: 6 June 2017

(c) Author(s) 2017. CC BY 3.0 License.
Hydrology and

Earth System

Sciences

Discussions

(c) (i)

Figure 10: Spatial agreement between the ensemble ET from remote sensing (a) and the SWAT simulated ET (b) at an annual basis

The monthly simulation for the entire Day Basin is presented in Figure 11. The observed values relate satisfactory to the ensemble ET values. Their peak values do not exceed $140 \mathrm{~mm} / \mathrm{month}$, while the modelled ET is as high as $160 \mathrm{~mm} / \mathrm{month}$. Another observation is that the lower ET values simulated during winter are always lower than the observed values from

5 remote sensing. This could be related to the dry period in which SWAT computes water stress due to a lack of soil moisture. This could suggest that the storage capacity of the soil in reality is higher, or it could also be related to lower vertical water fluxes between the top soil, sub-soil and the unconfined shallow aquifer, or the sensitivity of vegetation to soil moisture. A very low reference $\mathrm{ET}_{0}$ during winter could also be an explanation. SWAT-CUP ensured that the spatial patterns match rather well. Some local differences occur unavoidably due to the limited set of ET related parameters $(n=4)$ that were optimized. The agreement between SWAT and remote sensing data was expressed by means of the correlation coefficient and the bias.

In very general terns, the set of ET related equations in SWAT has a limited capacity to mimic the complex processes of soil evaporation, plant interception and plant transpiration that occur in reality due to the dynamic meteorological and hydrological processes. The good agreement reveals that both the ET formulations in SWAT as well as the SWAT-CUP optimization

15 techniques are adequate. The same conclusion was drawn earlier by other researchers that validate SWAT on the basis of ET data series.

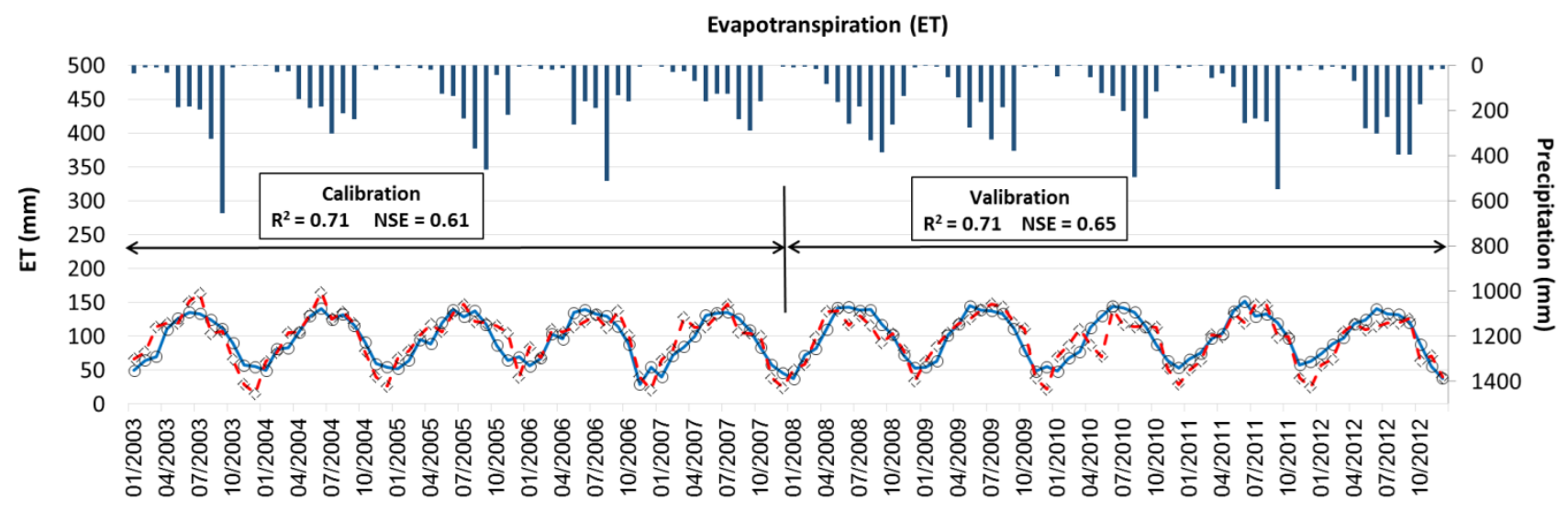

- Precipitation $\_$Ensemble ET $\quad$ - SWAT simulated ET

Figure 11: Monthly ET values estimated from SWAT and the "observed" values from remote sensing

20 Figure 12 represents the accumulated ET during the calibration (2003 to 2007) and validation (2008 to 2012) period. The total simulated ET is $5855 \mathrm{~mm}$, compared with $5727 \mathrm{~mm}$ for the ensemble ET during the calibration, hence a difference of $128 \mathrm{~mm}$ $(2.2 \%)$. The model performs consistently during the validation period with $5713 \mathrm{~mm}$ (simulated ET) as compared to $6015 \mathrm{~mm}$ 
Hydrol. Earth Syst. Sci. Discuss., https://doi.org/10.5194/hess-2017-251

Manuscript under review for journal Hydrol. Earth Syst. Sci.

Discussion started: 6 June 2017

(c) Author(s) 2017. CC BY 3.0 License.

(c) (i)
Hydrology and

Earth System

Sciences

Discussions

(ensemble ET) leading to a difference of $302 \mathrm{~mm}(5.3 \%)$. The results indicate that the model succeeded in generating a close to reality ET in both calibration and validation.
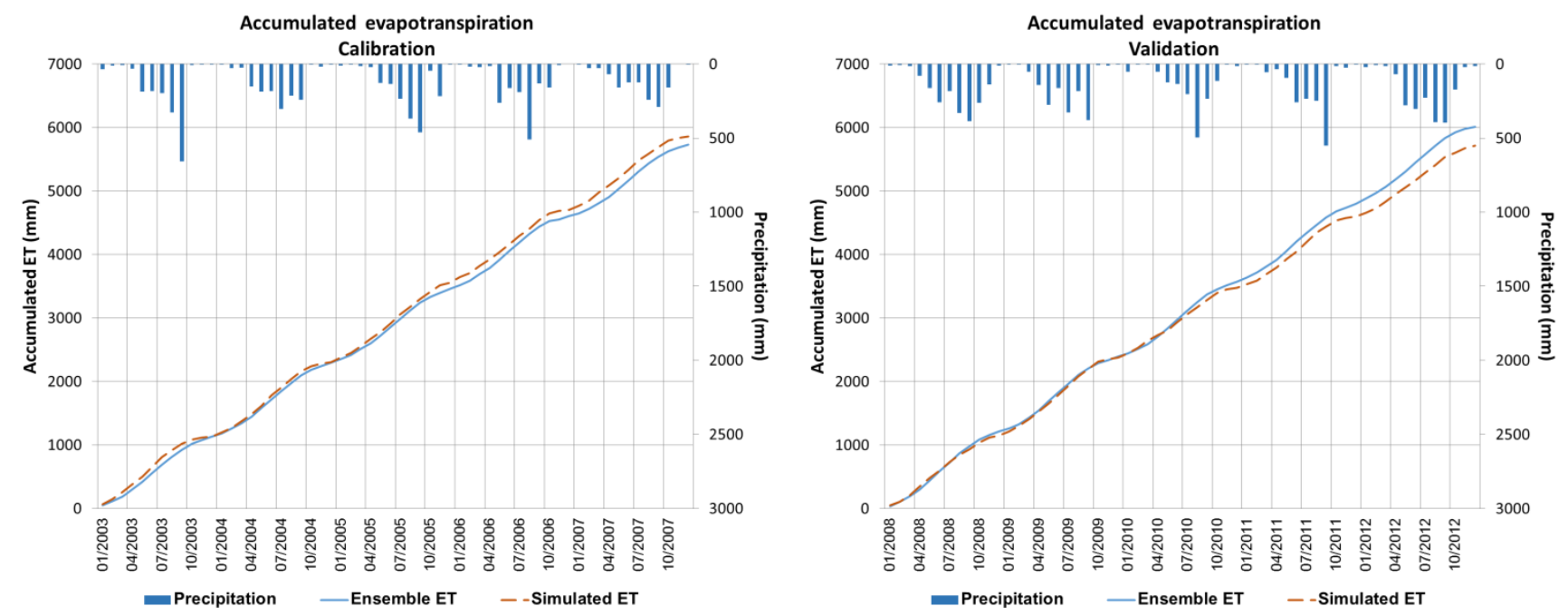

5 Figure 12: Accumulated ET for the calibration period of five years. The accumulated ET for the five year validation period is also depicted

The relationship between monthly river flow simulations and flow measurements at the Phu Ly and Ninh Binh stations is shown in Fig.13. . The $\mathrm{R}^{2}$ ranges from 0.71 (Phu Ly) to 0.78 (Ninh Binh) while Nash-Sutcliffe is 0.55 and 0.63, respectively.

10 Considering the uncertainty of the hydrograph, the agreement between simulated river flow and station discharge measurements is good. Measured river flow data were not used in the calibration process, which shows that a good simulation of ET will make it possible to calculate flows directly (Streamflow and ET being the two largest components of the water balance) without having to optimize flow in the calibration process. 
Hydrol. Earth Syst. Sci. Discuss., https://doi.org/10.5194/hess-2017-251

Manuscript under review for journal Hydrol. Earth Syst. Sci.

Discussion started: 6 June 2017

(c) Author(s) 2017. CC BY 3.0 License.

(c) (i)
Hydrology and

Earth System

Sciences

Discussions
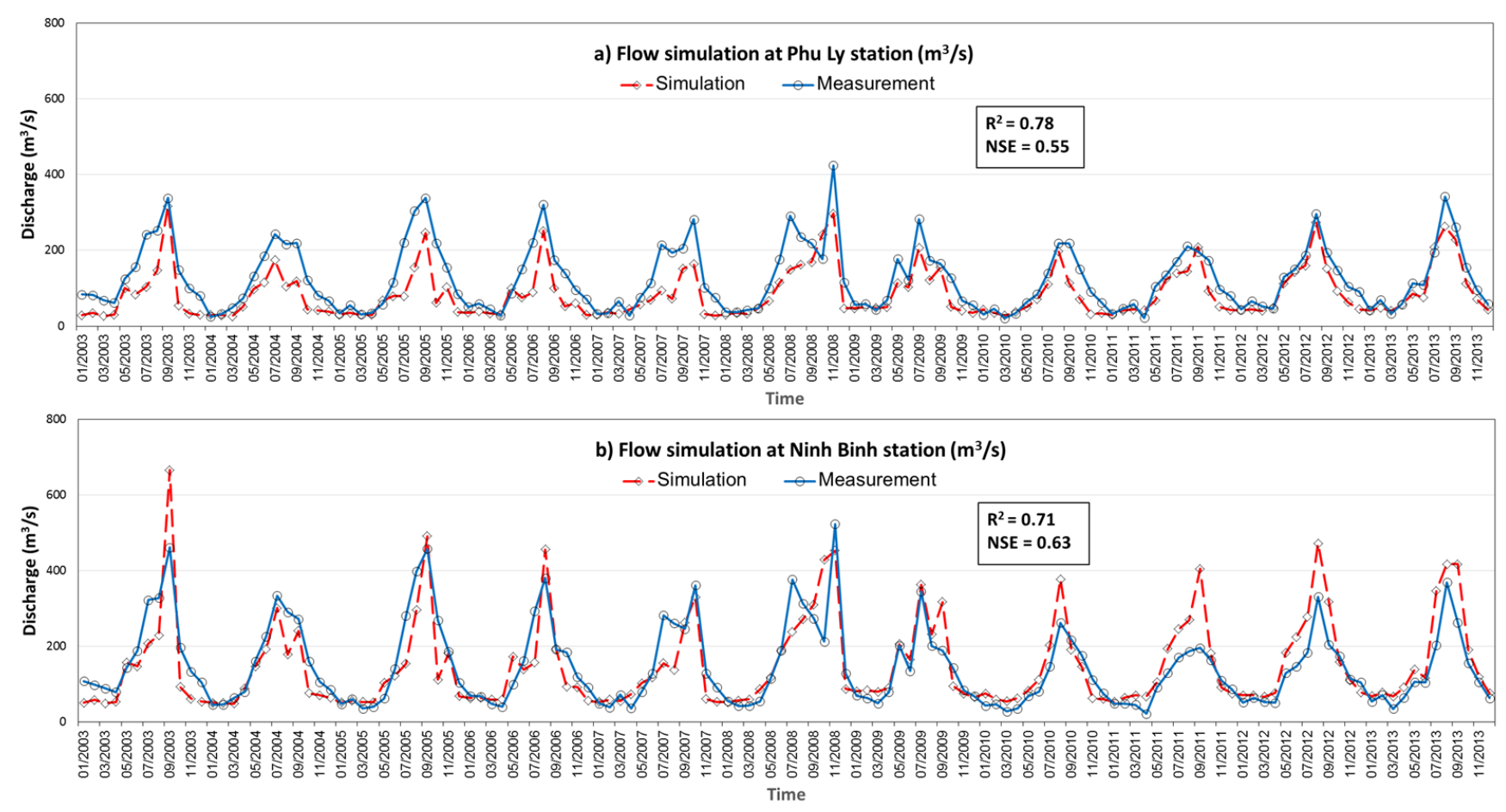

Figure 13: Flow simulation versus station measurements at Phu Ly (a) and Ninh Binh station (b)

The total water balance for the basin in an average precipitation year is showed in Table 2. The same information for a dry (2007) and a wet year (2008) is provided in the appendix. While the average annual rainfall was $1710 \mathrm{~mm} / \mathrm{yr}$, it reached a high

5 of $2121 \mathrm{~mm} / \mathrm{yr}$ in 2008 and a low of $1496 \mathrm{~mm} / \mathrm{yr}$ in 2007. The ET in 2007 and 2008 was 985 and $1010 \mathrm{~mm} / \mathrm{yr}$ respectively, compared to $958 \mathrm{~mm} / \mathrm{yr}$ on average. This quasi-constancy of ET is noticed more often in other studies. The regulating role of soil water storage in the vadose zone and the lower evaporative demand in wet years and higher demand during dry years are some major causing factors. The soil water content for 2007 was indeed negative $(\Delta \mathrm{SW}=-27 \mathrm{~mm} / \mathrm{yr}$ ) while for 2008 it was positive $(\Delta \mathrm{SW}=+80 \mathrm{~mm} / \mathrm{yr})$.

10

The total amount of irrigation water supply is computed to be 1.934 billion $\mathrm{m}^{3} / \mathrm{yr}$, and this amount of water is thus withdrawn from the Red River through various ungauged inlet points. This number can now be estimated with more precision because ET is known (Immerzeel and Droogers, 2008; Droogers et al., 2010; Gitau et al., 2011). The main water intake for irrigation is between January and March (during the Winter-Spring paddy rice) with a maximum amount of 98 mm during February.

15 During the Summer-Autumn paddy rice season, the water intake is concentrated in July with an amount of $113 \mathrm{~mm}$ per month. The total storage change $\Delta \mathrm{S}$ indicates the difference between all inflow and outflow terms. $\Delta \mathrm{S}$ during 2003 to 2013 for unsaturated and saturated zones are 11.7 and $9.6 \mathrm{~mm} / \mathrm{yr}$ respectively due to the fact that there is water locally stored in lakes, streams and also moving within the saturated layers to the deep aquifer. 
Hydrol. Earth Syst. Sci. Discuss., https://doi.org/10.5194/hess-2017-251

Manuscript under review for journal Hydrol. Earth Syst. Sci.

Discussion started: 6 June 2017

(c) Author(s) 2017. CC BY 3.0 License.

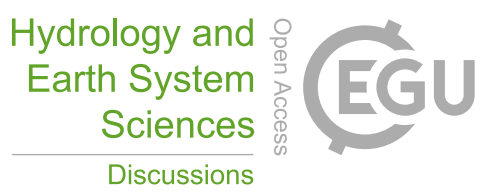

(c) (1)

Further to the water balance simulations of SWAT, the vegetation response to water can be evaluated by means of a comparison of the simulated LAI (see Fig.14). The timing of the green cover development seems acceptable. The peak LAI values during Spring 2005 and 2006 do, however, not agree very well. This may be due to constancy of the LAI related calibration parameters

5 for all the different simulation years. It would be better to make the maximum LAI parameter variable to enable it to better respond to years with weather anomalies. A good description of LAI evolution will improve the timing of rice emergence, which in turn affects the irrigation and transpiration processes. 
Hydrol. Earth Syst. Sci. Discuss., https://doi.org/10.5194/hess-2017-251

Manuscript under review for journal Hydrol. Earth Syst. Sci.

Discussion started: 6 June 2017

(c) Author(s) 2017. CC BY 3.0 License.

\section{(c) (i)}

Hydrology and Earth System Sciences

Discussions
Table 2: Monthly water balance for an average precipitation year, expressed in $\mathbf{m m} / \mathbf{y r}$

\begin{tabular}{|c|c|c|c|c|c|c|c|c|c|}
\hline \multicolumn{10}{|c|}{ Unsaturated zone } \\
\hline & \multicolumn{3}{|c|}{ Input } & \multicolumn{5}{|c|}{ Output } & \multirow{2}{*}{$\begin{array}{c}\Delta \mathrm{S} \\
\text { Input- } \\
\text { Output }\end{array}$} \\
\hline Month & $\mathrm{P}$ & IRR & Revap & Q & $\mathrm{Q}_{\text {lat }}$ & ET & PERC & $\Delta \mathrm{SW}$ & \\
\hline Jan & 11.7 & 56.8 & 1.2 & 1.7 & 0.9 & 28.6 & 38.5 & -4.7 & 4.6 \\
\hline Feb & 9.4 & 98.2 & 1.4 & 1.7 & 0.7 & 39.5 & 32.5 & 29.5 & 5.1 \\
\hline Mar & 19.8 & 19.1 & 1.7 & 1.8 & 0.6 & 66.1 & 30.3 & -23.0 & -35.2 \\
\hline Apr & 77.1 & 10.3 & 2.4 & 12.2 & 0.5 & 86.5 & 0.5 & 1.1 & -11.1 \\
\hline May & 231.9 & 8.7 & 2.5 & 50.0 & 0.5 & 120.5 & 6.7 & 42.9 & 22.4 \\
\hline Jun & 230.0 & 0.7 & 2.4 & 55.3 & 0.7 & 123.9 & 22.5 & 18.1 & 12.4 \\
\hline Jul & 286.7 & 112.6 & 2.4 & 110.6 & 1.1 & 125.6 & 108.4 & 18.1 & 37.9 \\
\hline Aug & 343.3 & 0.0 & 1.8 & 132.0 & 1.7 & 121.1 & 89.4 & -2.5 & 3.4 \\
\hline Sep & 330.8 & 0.0 & 1.2 & 151.0 & 2.1 & 99.8 & 75.2 & -3.4 & 7.3 \\
\hline Oct & 106.6 & 0.0 & 1.0 & 47.2 & 2.1 & 74.4 & 25.3 & -11.8 & -29.7 \\
\hline Nov & 53.7 & 0.8 & 0.8 & 22.2 & 1.7 & 44.3 & 11.8 & -9.9 & -14.7 \\
\hline Dec & 8.4 & 2.2 & 0.6 & 1.2 & 1.3 & 27.4 & 0.4 & -5.0 & -14.0 \\
\hline Total & 1709.5 & 309.2 & 19.4 & 586.9 & 14.0 & 957.9 & 441.5 & 49.5 & -11.7 \\
\hline
\end{tabular}

\begin{tabular}{|c|c|c|c|c|}
\hline \multicolumn{5}{|c|}{ Saturated zone } \\
\hline Input & & $\mathrm{Ou}$ & & $\Delta \mathrm{S}$ \\
\hline PERC & Revap & GW_RCH & SA_ST & $\begin{array}{l}\text { Input- } \\
\text { Output }\end{array}$ \\
\hline 38.5 & 1.2 & 34.5 & 0.0 & 2.8 \\
\hline 32.5 & 1.4 & 31.5 & -1.7 & 1.3 \\
\hline 30.3 & 1.7 & 36.2 & -2.2 & -5.5 \\
\hline 0.5 & 2.4 & 31.0 & -3.1 & -29.8 \\
\hline 6.7 & 2.5 & 27.9 & -3.2 & -20.5 \\
\hline 22.5 & 2.4 & 25.4 & -2.9 & -2.3 \\
\hline 108.4 & 2.4 & 31.3 & -2.5 & 77.3 \\
\hline 89.4 & 1.8 & 42.1 & -1.9 & 47.5 \\
\hline 75.2 & 1.2 & 46.4 & -1.6 & 29.2 \\
\hline 25.3 & 1.0 & 48.6 & -1.8 & -22.5 \\
\hline 11.8 & 0.8 & 42.7 & -1.5 & -30.2 \\
\hline 0.4 & 0.6 & 38.5 & -1.2 & -37.5 \\
\hline 441.5 & 19.4 & 436.1 & -23.6 & 9.6 \\
\hline
\end{tabular}

P: precipitation

ET: Evapotranspiration

Revap: Water revap from saturated to unsaturated layer $\Delta \mathrm{SW}$ : change in soil water content

Q

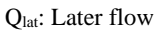

IRR: applied amount of irrigation water

Percolation: Percolation to saturated zone GW_RCH: Recharge to groundwater

SA_ST: Change in shallow aquifer storage 
Hydrol. Earth Syst. Sci. Discuss., https://doi.org/10.5194/hess-2017-251

Manuscript under review for journal Hydrol. Earth Syst. Sci.

Discussion started: 6 June 2017

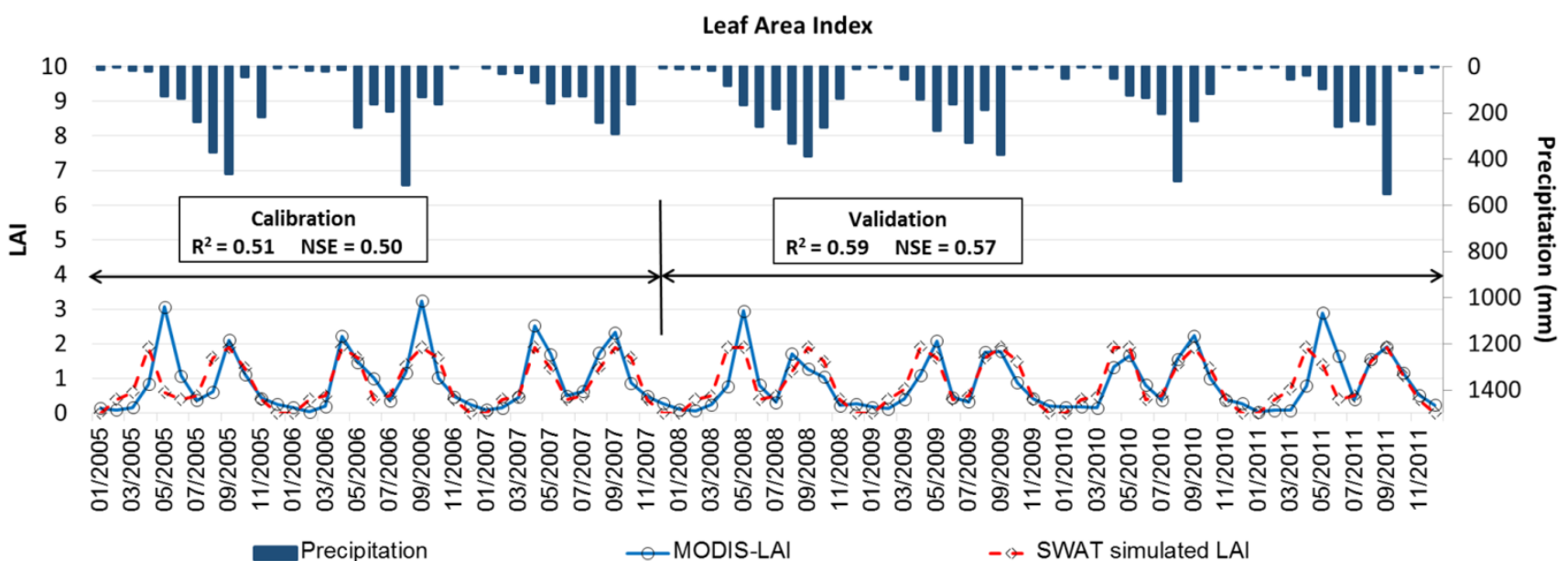

Figure 14: Determination of the LAI from MODIS (part A) and SWAT (B) for an HRU consisting of paddy rice

\section{Conclusions}

The availability of precipitation, ET and LAI gridded data from open access - or partially open access - earth observation data

platforms makes it feasible to calibrate soil and vegetation process parameters of eco-hydrological models, also when rivers are ungauged. This paper demonstrates that SWAT and SWAT-CUP meet the requirements for modelling and optimizing the bio-physical processes in data scarce basins. The essential bio-physical processes of the unsaturated zone and exchange processes that could be verified, seem to be adequately described in SWAT, otherwise there would not have been such a good agreement with the remote sensing parameters. The hydrological formulations in SWAT are thus adequate for simulating ecohydrological processes. It is recommend that maximum LAI is made variable for every year of simulation.

SWAT-CUP has the right design to optimize 15 model parameters simultaneously in a distributed manner. In the near-future, spatial data on soil moisture, net primary production and water quality will become available as well, and this will further enrich the calibration procedure. As far as the authors are aware this is the first time that the automated SWAT-CUP routine is applied with remote sensing data. The contribution of this paper is that SWAT-CUP can facilitate and standardize the calibration process for basins with scant field data, and that essential bio-physical parameters are estimated for every Hydrological Response Unit.

The ensemble ET product needs more research. In this study, four individual ET models were averaged linearly to match the simulations of ET from SWAT. In other studies, different and several (four to seven) ET models were included. By undertaking more studies, progressive insights on averaging of individual estimates will arise. 
Hydrol. Earth Syst. Sci. Discuss., https://doi.org/10.5194/hess-2017-251

Manuscript under review for journal Hydrol. Earth Syst. Sci.

Discussion started: 6 June 2017

(c) Author(s) 2017. CC BY 3.0 License.

(c) (1)

The integration of SWAT-CUP with earth observation data will make it feasible to swiftly estimate surface runoff, erosion, groundwater recharge, baseflow, storage changes, withdrawals, and carbon assimilation. This is a principal data set required to quantify ecosystems services, and optimize the economic profits while conserving the environment. The availability of the system parameters will allow future predictions of the basin water cycle in response to external factors such as climate and

land-use changes and computing scenario's for green growth.

\section{Acknowledgments}

This work was undertaken as part of the MK27 project "Inclusive development paths for healthy Red River landscapes based on ecosystem services" under the CGIAR Research Program on Water, Land and Ecosystems (WLE). The authors would like to express our gratitude for this support. Also thanks to Xuelong Chen (ITC) for providing the SEBS data. SSEBop ET was

10 provided by the U.S. Geological Survey Earth Resources Observation and Science Center. Any use of trade, firm, or product names is for descriptive purposes only and does not imply endorsement by the U.S. Government. 
Hydrol. Earth Syst. Sci. Discuss., https://doi.org/10.5194/hess-2017-251

Manuscript under review for journal Hydrol. Earth Syst. Sci.

Discussion started: 6 June 2017

(c) Author(s) 2017. CC BY 3.0 License.

(c) (1)
Hydrology and

Earth System

Sciences

Discussions

\section{APPENDIX}

Table 3: Monthly water balance for a dry year (2007) expressed in $\mathbf{m m} / \mathbf{y r}$

\begin{tabular}{|c|c|c|c|c|c|c|c|c|c|}
\hline \multicolumn{10}{|c|}{ Unsaturated zone } \\
\hline & \multicolumn{3}{|c|}{ Input } & \multicolumn{5}{|c|}{ Output } & \multirow{2}{*}{\begin{tabular}{|c|}
$\Delta \mathrm{S}$ \\
Input- \\
Output
\end{tabular}} \\
\hline Month & $\mathrm{P}$ & IRR & Revap & $\mathrm{Q}_{\text {runoff }}$ & $\mathrm{Q}_{\text {lat }}$ & ET & PERC & $\Delta \mathrm{SW}$ & \\
\hline Jan & 2.2 & 59.4 & 0.9 & 0.6 & 0.8 & 27.3 & 38.0 & -7.2 & 3.1 \\
\hline Feb & 27.1 & 79.3 & 1.1 & 3.8 & 0.5 & 46.7 & 23.8 & 31.9 & 0.8 \\
\hline Mar & 17.1 & 6.1 & 0.5 & 1.2 & 0.5 & 71.1 & 11.7 & -24.7 & -36.1 \\
\hline Apr & 84.4 & 11.3 & 0.2 & 16.8 & 0.4 & 78.6 & 0.2 & 13.4 & -13.6 \\
\hline May & 178.9 & 7.9 & 0.2 & 33.6 & 0.4 & 113.3 & 3.0 & 31.9 & 4.8 \\
\hline Jun & 192.5 & 0.0 & 0.2 & 38.6 & 0.6 & 132.7 & 8.3 & -4.6 & 17.1 \\
\hline Jul & 214.1 & 138.1 & 0.2 & 59.7 & 0.8 & 140.8 & 94.2 & -10.2 & 67.0 \\
\hline Aug & 238.5 & 0.0 & 0.1 & 52.8 & 1.0 & 137.0 & 40.9 & -0.9 & 7.7 \\
\hline Sep & 329.7 & 0.0 & 0.2 & 115.2 & 1.4 & 103.5 & 74.5 & 3.2 & 32.2 \\
\hline Oct & 207.9 & 0.0 & 0.1 & 125.0 & 2.0 & 80.0 & 53.0 & -40.6 & -11.3 \\
\hline Nov & 0.4 & 0.0 & 0.0 & 0.0 & 1.5 & 37.2 & 0.4 & -15.6 & -23.1 \\
\hline Dec & 3.2 & 0.0 & 0.0 & 0.1 & 1.1 & 16.8 & 0.0 & -3.8 & -11.0 \\
\hline Total & 1496.1 & 302.0 & 3.6 & 447.2 & 11.1 & 985.0 & 347.9 & -27.1 & 37.7 \\
\hline
\end{tabular}

\begin{tabular}{|l|l|l|l|l|}
\hline \multicolumn{5}{|c|}{ Saturated zone } \\
\hline \multicolumn{1}{|c|}{ Input } & \multicolumn{3}{c|}{ Output } \\
\hline Percolation & Revap & GW_RCH & SA_ST & $\begin{array}{l}\text { Input- } \\
\text { Output }\end{array}$ \\
\hline 38.0 & 0.9 & 31.2 & 0.0 & 5.9 \\
\hline 23.8 & 1.1 & 28.2 & -2.1 & -3.3 \\
\hline 11.7 & 0.5 & 30.6 & -1.5 & -17.8 \\
\hline 0.2 & 0.2 & 25.7 & -0.8 & -24.9 \\
\hline 3.0 & 0.2 & 23.0 & -0.8 & -19.4 \\
\hline 8.3 & 0.2 & 20.1 & -0.8 & -11.2 \\
\hline 94.2 & 0.2 & 24.5 & -0.3 & 69.9 \\
\hline 40.9 & 0.1 & 31.8 & -0.5 & 9.5 \\
\hline 74.5 & 0.2 & 33.8 & -0.3 & 40.8 \\
\hline 53.0 & 0.1 & 41.1 & -0.3 & 12.0 \\
\hline 0.4 & 0.0 & 36.1 & -0.3 & -35.4 \\
\hline 0.0 & 0.0 & 32.1 & -0.2 & -31.9 \\
\hline $\mathbf{3 4 7 . 9}$ & $\mathbf{3 . 6}$ & $\mathbf{3 5 8 . 0}$ & $\mathbf{- 7 . 8}$ & $\mathbf{- 5 . 9}$ \\
\hline & & & & \\
\hline
\end{tabular}

P: precipitation

ET: Evapotranspiration

Revap: Water revap from saturated to unsaturated layer

$\Delta \mathrm{SW}$ : change in soil water content

Qrunoff: generated surface flow, including surface runoff,

Qlat: Later flow
IRR: applied amount of irrigation water Percolation: Percolation to saturated zone GW_RCH: Recharge to groundwater

SA_ST: Change in shallow aquifer storage

Table 4: Monthly water balance for a wet year (2008) expressed in $\mathrm{mm} / \mathrm{yr}$

\begin{tabular}{|c|c|c|c|}
\hline \multicolumn{3}{|c|}{ Unsaturated zone } & $\Delta \mathrm{S}$ \\
\hline & Input & Output & \\
\hline
\end{tabular}

\begin{tabular}{|c|c|c|}
\hline \multicolumn{3}{|c|}{ Saturated zone } \\
\hline Input & Output & $\Delta \mathrm{S}$ \\
\hline
\end{tabular}


Hydrol. Earth Syst. Sci. Discuss., https://doi.org/10.5194/hess-2017-251

Manuscript under review for journal Hydrol. Earth Syst. Sci.

Discussion started: 6 June 2017

(c) Author(s) 2017. CC BY 3.0 License.

(c) (i)
Hydrology and

Discussions

\begin{tabular}{|l|l|l|l|l|l|l|l|l|l|}
\hline Month & P & IRR & Revap & $Q_{\text {runoff }}$ & Q lat & ET & PERC & $\Delta$ SW & $\begin{array}{c}\text { Input- } \\
\text { Output }\end{array}$ \\
\hline Jan & 13.2 & 61.7 & 0.0 & 1.2 & 0.9 & 22.6 & 41.3 & 2.2 & 6.8 \\
\hline Feb & 3.9 & 118.4 & 0.1 & 1.2 & 0.6 & 26.4 & 44.9 & 39.8 & 9.4 \\
\hline Mar & 16.6 & 78.7 & 0.0 & 1.7 & 0.6 & 73.8 & 72.9 & -34.5 & -19.2 \\
\hline Apr & 89.0 & 3.8 & 0.0 & 16.9 & 0.5 & 99.5 & 1.2 & -17.1 & -8.0 \\
\hline May & 198.6 & 1.9 & 0.0 & 37.0 & 0.5 & 125.5 & 0.4 & 26.0 & 11.3 \\
\hline Jun & 301.0 & 0.0 & 0.0 & 69.7 & 0.7 & 123.6 & 24.4 & 35.1 & 47.5 \\
\hline Jul & 269.8 & 111.2 & 0.0 & 86.9 & 1.3 & 131.7 & 129.7 & -11.6 & 43.1 \\
\hline Aug & 346.5 & 0.0 & 0.0 & 111.9 & 1.8 & 128.8 & 85.7 & 8.4 & 9.9 \\
\hline Sep & 331.7 & 0.0 & 0.2 & 119.5 & 2.2 & 105.5 & 85.2 & 19.9 & -0.5 \\
\hline Oct & 347.0 & 0.0 & 0.1 & 202.3 & 2.4 & 76.8 & 46.9 & 57.5 & -38.8 \\
\hline Nov & 194.6 & 0.0 & 0.3 & 140.5 & 2.5 & 57.8 & 73.0 & -38.1 & -40.8 \\
\hline Dec & 9.1 & 0.0 & 0.0 & 0.4 & 2.0 & 37.6 & 0.7 & -7.4 & -24.1 \\
\hline Total & $\mathbf{2 1 2 1 . 1}$ & $\mathbf{3 7 5 . 7}$ & $\mathbf{0 . 7}$ & $\mathbf{7 8 9 . 1}$ & $\mathbf{1 5 . 8}$ & $\mathbf{1 0 0 9 . 5}$ & $\mathbf{6 0 6 . 2}$ & $\mathbf{8 0 . 1}$ & $\mathbf{- 3 . 2}$ \\
\hline
\end{tabular}

\begin{tabular}{|l|l|l|l|l|}
\hline Percolation & Revap & GW_RCH & SA_ST & $\begin{array}{l}\text { Input- } \\
\text { Output }\end{array}$ \\
\hline 41.3 & 0.0 & 30.5 & 0.0 & 10.8 \\
\hline 44.9 & 0.1 & 29.3 & 0.0 & 15.5 \\
\hline 72.9 & 0.0 & 38.9 & 0.0 & 33.9 \\
\hline 1.2 & 0.0 & 35.1 & -0.2 & -33.8 \\
\hline 0.4 & 0.0 & 31.3 & -0.2 & -30.7 \\
\hline 24.4 & 0.0 & 27.1 & 0.0 & -2.7 \\
\hline 129.7 & 0.0 & 35.6 & 0.6 & 93.4 \\
\hline 85.7 & 0.0 & 46.1 & 0.3 & 39.3 \\
\hline 85.2 & 0.2 & 50.9 & 0.1 & 34.0 \\
\hline 46.9 & 0.1 & 54.8 & -0.2 & -7.9 \\
\hline 73.0 & 0.3 & 55.9 & -0.1 & 16.9 \\
\hline 0.7 & 0.0 & 52.0 & -0.3 & -51.0 \\
\hline $\mathbf{6 0 6 . 2}$ & $\mathbf{0 . 7}$ & $\mathbf{4 8 7 . 7}$ & $\mathbf{0 . 0}$ & $\mathbf{1 1 7 . 9}$ \\
\hline
\end{tabular}

P: precipitation

ET: Evapotranspiration

Revap: Water revap from saturated to unsaturated layer

$\Delta \mathrm{SW}$ : change in soil water content

Qrunoff: generated surface flow, including surface runoff,

Q
IRR: applied amount of irrigation water

Percolation: Percolation to saturated zone

GW_RCH: Recharge to groundwater

SA_ST: Change in shallow aquifer storage 
Hydrol. Earth Syst. Sci. Discuss., https://doi.org/10.5194/hess-2017-251

Manuscript under review for journal Hydrol. Earth Syst. Sci.

Discussion started: 6 June 2017

(c) Author(s) 2017. CC BY 3.0 License.

\section{References}

1. Abbaspour, K.C.: SWAT-CUP: SWAT Calibration and Uncertainty Programs - A User Manual, Department of Systems Analysis, Integrated Assessment and Modelling (SIAM), Eawag. Swiss Federal Institute of Aquatic Science and Technology, Duebendorf, Switzerland. 100 p. 2015.

5 2. Abbaspour, K.C., Rouholahnejad, E., Vaghefi, S., Srinivasan, R., Yang H., and Kløve, B.: A continental-scale hydrology and water quality model for Europe: Calibration and uncertainty of a high-resolution large-scale SWAT model, J. Hydrol., 524, 733-752, doi:10.1016/j.jhydrol.2015.03.027, 2015.

3. Abbaspour, K. C., van Genuchten, M. T., Schulin, R., and Schläppi, E.: A sequential uncertainty domain inverse procedure for estimating subsurface flow and transport parameters, Water Resour. Res., 33, 1879-1892, doi:10.1029/97WR01230, 1997.

4. Abdullahi, A.S., Soom, M.A.M., Ahmad, D., and Shariff, A.R.M.: Characterization of rice (Oryza sativa) evapotranspiration using micro paddy lysimeter and class "A" pan in tropical environments, Australian Journal of Crop Science, 7, 650-680, 2013.

5. Allen, R.G., Pereira, L.S., Raes, D., and Smith, M.: Crop evapotranspiration: guidelines for computing crop water requirements, FAO Irrigation and Drainage Paper No. 56, FAO, Rome, Italy, 300 pp, 1998.

6. Allen, R.G., Trezza, R., and Tasumi, M.: Analytical integrated functions for daily solar radiation on slopes, Agric. For. Meteorol., 139, 55-73, doi: 10.1016/j.agrformet.2006.05.012, 2006.

7. Arnold, J. G., Srinivasan, R., Muttiah, R. S., and Williams, J .R.: Large-area hydrologic modeling and assessment: Part I. Model development, J. Am. Water Resour. Assoc., 34, 73-89, doi:10.1111/j.1752-1688.1998.tb05961.x, 1998.

20 8. Arnold, J.G., Moriasi, D.N., Gassman, P.W., Abbaspour, K.C., White, M.J., Srinivasan, R., Santhi, C., Harmel, R.D., Van Griensven, A., Van Liew, M.W., Kannan, N., and Jha, M.K.: SWAT: Model use, calibration, and validation. T. ASABE., 55, 1491-1508, doi:10.13031/2013.42256, 2012.

9. Bagstad, K.J., Johnson, G.W., Voigt, B., and Villa, F.: Spatial dynamics of ecosystem service flows: a comprehensive approach to quantifying actual services, Ecosyst. Serv., 4, 117-125, doi:10.1016/j.ecoser.2012.07.012, 2013.

10. Bastiaanssen, W.G.M., and Harshadeep, N.R.: Managing scarce water resources in Asia: The nature of the problem and can remote sensing help?, Irrig Drainage Syst, 19, 269-284, doi:10.1007/s10795-005-5188-y, 2005.

11. Bréda, N.J.J.: Ground-based measurements of leaf area index: a review of methods, instruments and current controversies, J. Exp. Bot., 54 (392): 2403-2417. doi: 10.1093/jxb/erg263, 2003.

12. Carlson, T. N., and Ripley, D. A.: On the relation between NDVI, fractional vegetation cover, and leaf area index, Remote Sens. Environ., 62, 241-252, 1997.

13. Cheema, M.J.M., Immerzeel, W.W. and Bastiaanssen, W.G.M. (2014), Spatial Quantification of Groundwater Abstraction in the Irrigated Indus Basin. Ground Water, 52: 25-36. doi:10.1111/gwat.12027 
Hydrol. Earth Syst. Sci. Discuss., https://doi.org/10.5194/hess-2017-251

Manuscript under review for journal Hydrol. Earth Syst. Sci.

Discussion started: 6 June 2017

(c) Author(s) 2017. CC BY 3.0 License.
Hydrology and

Earth System

Sciences

Discussions

14. Chen, X., Su, Z., Ma, Y., Yang, K., Wen, J. and Zhang, Y.: An Improvement of Roughness Height Parameterization of the Surface Energy Balance System (SEBS) over the Tibetan Plateau, J. Appl. Meteorol. Climatol., 52 (3), 607-622, doi:10.1175/JAMC-D-12-056.1, 2013.

15. Cibin, R., Sudheer K. P., and Chaubey I.: Sensitivity and identifiability of stream flow generation parameters of the SWAT model, Hydrol. Process, 24(9), 1133 - 1148, doi:10.1002/hyp.7568, 2010.

16. Crossman, N.D., Burkhard, B., Nedkov, S., Willemen, L., Petz, K., Palomo, I., Drakou, E.G., Martín-Lopez, B., McPhearson, T., Boyanova, K., Alkemade, R., Egoh, B., Dunbar, M.B., and Maes, J.: A blueprint for mapping and modelling ecosystem services, Ecosyst. Serv., 4, 4-14, doi:10.1016/j.ecoser.2013.02.001, 2013.

17. Dechmi, F., Burguete, J., Skhiri, A.: SWAT application in intensive irrigation systems: Model modification, calibration and validation, J. Hydrol., 470-471, 227-238, doi:10.1016/j.jhydrol.2012.08.055, 2012.

18. Droogers, P. and Bastiaanssen, W.G.M.: Irrigation Performance using Hydrological and Remote Sensing Modeling, J. Irrig. Drain Eng., 11-18, doi:10.1061/(ASCE)0733-9437(2002)128:1(11), 2002.

19. Droogers, P., Immerzeel, W.W., and Lorite, I.J.: Estimating actual irrigation application by remotely sensed evapotranspiration observations, Agric. Water Manage., 97, 1351 - 1359,http://dx.doi.org/10.1016/j.agwat.2010.03.017, 2010.

20. Food and Agricultural Organization (FAO): The Digital Soil Map of the World and Derived Soil Properties [CD-ROM], Version 3.5, Rome, 1995.

21. Francesconi, W., Srinivasan, R., Pérez-Miñana, E., Willcock, S.P., and Quintero. M. : Using the Soil and Water Assessment Tool (SWAT) to model ecosystem services: A systematic review. J. Hydrol., 535, 625-636. doi:10.1016/j.jhydrol.2016.01.034, 2016.

22. Funk, C.C., Peterson, P.J., Landsfeld, M.F., Pedreros, D.H., Verdin, J.P., Rowland, J.D., Romero, B.E., Husak, G.J., Michaelsen, J.C., and Verdin, A.P., A quasi-global precipitation time series for drought monitoring: U.S. Geological Survey Data Series 832, 4 p., doi:10.3133/ds832, 2014.

23. Gitau, M. W., and Chaubey I.: Regionalization of SWAT Model Parameters for Use in Ungauged Watersheds, Water, 2 , 849-871, doi:10.3390/w2040849, 2010.

24. Githui, F., Selle, B., and Thayalakumaran, T.: Recharge estimation using remotely sensed evapotranspiration in an irrigated catchment in southeast Australia, Hydrol. Process., 26 , 1379-1389, DOI: 10.1002/hyp.8274, 2011.

25. Giuliani, M., Anghileri, D., Castelletti, A., Vu, P.N., and Soncini-Sessa, R.: Large storage operations under climate change: expanding uncertainties and evolving tradeoffs, Environ. Res. Lett., 11, 035009, doi:10.1088/17489326/11/3/035009, 2016.

26. Hargreaves, G., Hargreaves, G., and Riley, J.: Agricultural Benefits for Senegal River Basin, J. Irrig. Drain Eng., 111, 113-124, doi:10.1061/(ASCE)0733-9437(1985)111:2(113), 1985. 
Hydrol. Earth Syst. Sci. Discuss., https://doi.org/10.5194/hess-2017-251

Manuscript under review for journal Hydrol. Earth Syst. Sci.

Discussion started: 6 June 2017

(c) Author(s) 2017. CC BY 3.0 License.
Hydrology and

Earth System

Sciences

Discussions

(c) (i)

27. Hengl, T., de Jesus, J.M., MacMillan, R.A., Batjes, N.H., Heuvelink, G.B.M., Ribeiro, E., Samuel-Rosa, A., Kempen, B., Leenaars, J.G.B., Walsh, M.G., and Ruiperez Gonzalez, M.: SoilGrids1km — Global Soil Information Based on Automated Mapping. PLoS ONE 9, e105992, doi:10.1371/journal.pone.0105992, 2014.

28. Hu, G., Jia, L., and Menenti, M.: Comparison of MOD16 and LSA-SAF MSG evapotranspiration products over Europe for 2011, Remote Sens. Environ., 156, 510-526, doi:10.1016/j.rse.2014.10.017, 2015.

29. Immerzeel, W. W., and Droogers, P.: Calibration of a distributed hydrological model based on satellite evapotranspiration. J. Hydrol., 349, 411-424, doi:10.1016/j.jhydrol.2007.11.017, 2008.

30. Immerzeel, W. W., Gaur, A., and Zwart, S. J.: Integrating remote sensing and a process-based hydrological model to evaluate water use and productivity in a south Indian catchment, Agr. Water Manage., 95, 11-24, doi:10.1016/j.agwat.2007.08.006, 2008.

31. Jhorar, R.K., Smit, A.A.M.F.R., Bastiaanssen, W.G.M., and Roest, C.W.J.: Calibration of a distributed irrigation water management model using remotely sensed evapotranspiration rates and groundwater heads, Irrig. and Drain., 60, 57-69, doi:10.1002/ird.541, 2011.

32. Kalma, J. D., McVicar, T. R., and McCabe, M. F.: Estimating Land Surface Evaporation: A Review of Methods Using Remotely Sensed Surface Temperature Data, Surv Geophys, 29, 421-469, doi:10.1007/s10712-008-9037-z, 2008.

33. Karimi, P., Bastiaanssen, W. G. M., and Molden, D.: Water Accounting Plus (WA+) - a water accounting procedure for complex river basins based on satellite measurements, Hydrol. Earth Syst. Sci., 17, 2459-2472, doi:10.5194/hess-17-2459$2013,2013$.

34. Karimi, P. and Bastiaanssen, W.G. M.: Spatial evapotranspiration, rainfall and land use data in water accounting - Part 1: Review of the accuracy of the remote sensing data, Hydrol. Earth Syst. Sci., 19, 507-532, doi:10.5194/hess-19-507-2015, 2015 .

35. Kim, H.W., Hwang, K., Mu, Q., Lee, O.S., and Choi, M.: Validation of MODIS 16 global terrestrial evapotranspiration products in various climates and land cover types in Asia, KSCE J. Civil Eng., 16, 229-238, doi:10.1007/s12205-0120006-1, 2012.

25 36. Knipper, K.R., Kinoshita, A.M., and Hogue, T.S.: Evaluation of a moderate resolution imaging spectroradiometer trianglebased algorithm for evapotranspiration estimates in subalpine regions, J. Appl. Remote Sens. 10, 016002, doi:10.1117/1.JRS.10.016002.

37. Le, T.P.Q., Billen, G., Garnier, J., Théry, S., Fézard, C., and Chau, V.M.: Nutrient (N, P) budgets for the Red River basin (Vietnam and China). Glob. Biogeochem. Cycles, 19, GB2022, doi: 10.1029/2004GB002405, 2005.

30 38. Li, Z.-L., Tang, R., Wan, Z., Bi, Y., Zhou, C., Tang, B., Yan, G., and Zhang, X : A Review of Current Methodologies for Regional, Evapotranspiration Estimation from Remotely Sensed Data, Sensors, 9, 3801-3853, doi:10.3390/s90503801, 2009.

39. Liang, X., Lettenmaier, D.P., Wood, E.F., and Burges, S.J.: A Simple hydrologically Based Model of Land Surface Water and Energy Fluxes for GSMs, J. Geophys. Res., 99, 14,415-14,428, 10.1029/94JD00483, 1994. 
Hydrol. Earth Syst. Sci. Discuss., https://doi.org/10.5194/hess-2017-251

Manuscript under review for journal Hydrol. Earth Syst. Sci.

Discussion started: 6 June 2017

(c) Author(s) 2017. CC BY 3.0 License.
Hydrology and

Earth System

Sciences

Discussions

(c) (i)

40. Luu, T.N.M., Garnier, J., Billen, G., Orange, D., Néméry, J., Le, T.P.Q., Tran, H.T., and Le, L.A.: Hydrological regime and water budget of the Red River Delta (Northern Vietnam). J. Asian. Earth. Sci., 37, 219-228, doi:10.1016/j.jseaes.2009.08.004, 2010.

41. Melesse, A.M., Weng, Q., Thenkabail, P.S., and Senay, G.B.: Remote Sensing Sensors and Applications in Environmental Resources Mapping and Modelling, Sensors, 7, 3209-3241, doi:10.3390/s7123209, 2007.

42. Meng, J., Li L., Hao, Z., Wang, J., and Shao, Q.: Suitability of TRMM satellite rainfall in driving a distributed hydrological model in the source region of yellow river. J Hydrol., 509, 320-332. doi:10.1016/j.jhydrol.2013.11.049, 2014.

43. Miralles, D. G., Holmes, T. R. H., De Jeu, R. A. M., Gash, J. H., Meesters, A. G. C. A., and Dolman, A. J.: Global landsurface evaporation estimated from satellite-based observations, Hydrol. Earth Syst. Sci., 15, 453-469, doi:10.5194/hess15-453-2011, 2011.

44. Mohan, S., and Arumugam, N.: Irrigation crop coefficients for lowland rice, Irrig. Drainage Syst., 8, 159:176, doi:10.1007/BF00881016, 1994.

45. Molden, D.: Accounting for water use and productivity, SWIM paper 1, International Irrigation Management Institute, Colombo, Sri Lanka, 26 pp, 1997.

15 46. Molden, D., Frenken, K., Barker, R., de Fraiture, C., Mati, B., Svendsen, M., Sadoff, C., and Finlayson, C. M.: Trends in water and agricultural development. In: Molden, D. (ed.), Water for food, water for life: A Comprehensive Assessment of Water Management in Agriculture. London, UK: Earthscan, Colombo, Sri Lanka: IWMI. pp.57-89, 2007.

47. Monteith, J. L.: Evaporation and the environment. The State and Movement of Water in Living Organisms, Symp. of the Society for Experimental Biology, No. 19, University Press, 205-234, 1965.

48. Mu, Q.Z., Heinsch, F.A., Zhao, M., and Running, S.W.: Development of a global evapotranspiration algorithm based on MODIS and global meteorology data, Remote Sens. Environ., 111, 519-536, doi:10.1016/j.rse.2007.04.015, 2007.

49. Mueller, D.S., Wagner, C.R., Rehmel, M.S., Oberg, K.A., and Rainville, F.: Measuring discharge with acoustic Doppler current profilers from a moving boat (ver. 2.0, December 2013), U.S. Geological Survey Techniques and Methods, book 3, chap. A22, 95 p., doi:10.3133/tm3A22, 2013.

50. Neale, C. M. U. and Cosh, M. H.: Remote sensing and hydrology, IAHS Red Book Series, Publ. 352, IAHS Wallingford, UK, 482 pp., 2010.

51. Neitsch, S.L., Arnold, J.G., Kiniry, J.R., and Williams, J.R.: Soil and Water Assessment Tool Theoretical Documentation Version 2009. Texas Water Resources Institute, 2011.

52. Someth Paradis and Räsänen Timo. 2012. Annex to Land Use Suitability for Agriculture in the Sesan Catchment: Crop Water Requirement and Irrigation Schedule. Project report: Challenge Program on Water \& Food Mekong project MK3 "Optimizing the management of a cascade of reservoirs at the catchment level". ICEM - International Centre for Environmental Management, Hanoi Vietnam, 2013 
Hydrol. Earth Syst. Sci. Discuss., https://doi.org/10.5194/hess-2017-251

Manuscript under review for journal Hydrol. Earth Syst. Sci.

Discussion started: 6 June 2017

Hydrology and

Earth System

(c) Author(s) 2017. CC BY 3.0 License.

Sciences

Discussions

(c) (i)

53. Pena-Arancibia, Jorge L., van Dijk, Albert I. J. M., Renzullo, Luigi J., and Mulligan, M.: Evaluation of Precipitation Estimation Accuracy in Reanalyses, Satellite Products, and an Ensemble Method for Regions in Australia and South and East Asia, J. Hydrometeorol., 14, 1323-1333, doi:10.1175/JHM-D-12-0132.1, 2013.

54. Pietroniro, A. and Leconte, R.: A review of Canadian remote sensing applications in hydrology, 1995-1999, Hydrol. Process., 14, 1641-1666, doi:10.1002/1099-1085(20000630)14:9<1641::AID-HYP75>3.0.CO;2-I, 2000.

55. Priestley, C. H. B. and Taylor, R. J.: On the assessment of surface heat flux and evaporation using large scale parameters. Mon. Weather Rev., 100, 81-92, doi: 10.1175/1520-0493(1972)100<0081:OTAOSH>2.3.CO;2, 1972.

56. Raghavan, S., Tue, V.M., and Shie-Yui, L.: Impact of climate change on future stream flow in the Dakbla river basin, J. Hydroinform., 16(1), 231-244, doi:10.2166/hydro.2013.165, 2014.

57. Ramoelo, A., Majozi, N., Mathieu, R., Jovanovic, N., Nickless, A., and Dzikiti, S.: Validation of Global Evapotranspiration Product (MOD16) using Flux Tower Data in the African Savanna, South Africa, Remote Sens., 6, 7406-7423, doi:10.3390/rs6087406, 2014.

58. Rodell, M., Houser, P.R., Jambor, U., Gottschalck, J., Mitchell, K., Meng, C.-J., Arsenault, K., Cosgrove, B., Radakovich, J., Bosilovich, M., Entin, J.K., Walker, J.P., Lohmann, D., and Toll, D.: The Global Land Data Assimilation System, Bull. Amer. Meteor. Soc., 85, 381-394, doi:10.1175/BAMS-85-3-381, 2004.

59. Rouholahnejad, E., Abbaspour, K.C., Vejdani, M., Srinivasan, R., Schulin, R., and Lehmannm A.: A parallelization framework for calibration of hydrological models, Environ modell softw, doi:10.1016/j.envsoft.2011.12.001, 2011.

60. Schneider, K., Ketzer, B., Breuer, L., Vaché, K. B., Bernhofer, C., and Frede, H.-G.: Evaluation of evapotranspiration methods for model validation in a semi-arid watershed in northern China, Adv. Geosci., 11, 37-42, doi:10.5194/adgeo11-37-2007, 2007.

61. Schuurmans, J. M., Troch, P. A., Veldhuizen, A. A., Bastiaanssen, W. G. M., and Bierkens, M. F. P.: Assimilation of remotely sensed latent heat flux in a distributed hydrological model, Adv. Water Resour., 26(2), 151-159, doi:10.1016/S0309-1708(02)00089-1, 2003.

62. Senay, G.B., Budde, M., Verdin, J.P., and Melesse, A.M.: A coupled remote sensing and simplified surface energy balance approach to estimate actual evapotranspiration from irrigated fields, Sensors, 7, 979-1000, doi:10.3390/s7060979 , 2007.

63. Senay, G. B., Leake, S., Nagler, P. L., Artan, G., Dickinson, J., Cordova, J. T., and Glenn E. P.: Estimating Basin Scale Evapotranspiration (ET) by Water Balance and Remote Sensing Methods, Hydrol. Process. 25, 4037-4049, doi: 10.1002/hyp.8379, 2011.

64. Senay, G. B., Bohms, S., Singh, R. K., Gowda, P. H., Velpuri, N. M., Alemu, H., and Verdin, J.: Operational evapotranspiration modeling using remote sensing and weather datasets: a new parameterization for the SSEB ET approach, J. Am. Water Resour. Assoc., 1-15. doi:10.1111/jawr.12057, 2013.

65. Serrat-Capdevila, A., Valdes, J.B., and Stakhiv, E.Z.: Water Management Applications for Satellite precipitation products: Synthesis and Recommendations, J. Am. Water Resour. Assoc., 50, 509-525, doi:10.1111/jawr.12140, 2014. 
Hydrol. Earth Syst. Sci. Discuss., https://doi.org/10.5194/hess-2017-251

Manuscript under review for journal Hydrol. Earth Syst. Sci.

Discussion started: 6 June 2017

(c) Author(s) 2017. CC BY 3.0 License.
Hydrology and

Earth System

Sciences

Discussions

66. Shrestha, B., Babel, M. S., Maskey, S., van Griensven, A., Uhlenbrook, S., Green, A., and Akkharath, I.: Impact of climate change on sediment yield in the Mekong River basin: a case study of the Nam Ou basin, Lao PDR, Hydrol. Earth Syst. Sci., 17, 1-20, doi:10.5194/hess-17-1-2013, 2013.

67. Simons, G.W.H., Bastiaanssen, W.G.M., Ngô, L.A., Hain, C.R., Anderson, M.C., and Senay, G.B.: Integrating Global Satellite-Derived Data Products as a Pre-Analysis for Hydrological Modelling Studies: A Case Study for the Red River Basin, Remote Sens., 8, 279-306, doi:10.3390/rs8040279, 2016.

68. Stisen, S., Jensen, K.H., Sandholt, I., and Grimes, D.I.: A remote sensing driven distributed hydrological model of the Senegal River basin: a remote sensing-driven model, J. Hydrol., 354, 1-4, 131-148., doi:10.1016/j.jhydrol.2008.03.006, 2008 .

10 69. Sousa, A.M.L., Vitorino, M.I., Castro, N.M.R., Botelho, M.N., and Souza, P.J.O.P.: Evapotranspiration from Remote Sensing to Improve the Swat Model in Eastern Amazonia, Floresta e Ambiente, 22, 456-464, doi:10.1590/21798087.083814, 2015.

70. Srinivasan, R., Zhang, X., and Arnold, J.G.: SWAT ungauged: Hydrological budget and crop yield predictions in the upper Mississippi river basin, T. ASABE., 53, 1533-1546, doi:10.13031/2013.34903, 2010.

15 71. Su, Z.: The Surface Energy Balance System (SEBS) for estimation of turbulent heat fluxes, Hydrol. Earth Syst. Sci., 6, 85-100, doi:10.5194/hess-6-85-2002, 2002.

72. Sun, C., Jiang, D., Wang, J., and Zhu, Y.: Validating remote sensing derived evapotranspiration with the soil and water assessment tool (SWAT) model: A case study in Zhelin Basin, China, Afr. J. Agric. Res., 8, 2090-2098, doi:10.5897/AJAR11.523, 2013.

20 73. Tallis, H. and Polasky, S.: Mapping and valuing ecosystem services as an approach for conservation and natural-resource management, The Year in Ecology and Conservation Biology, Ann. N.Y. Acad. Sci., 1162, 265-283, doi: 10.1111/j.17496632.2009.04152.x, 2009.

74. Templeton, R. C., Vivoni, E. R., Méndez-Barroso, L. A., Pierini, N. A., Anderson, C. A., Rango, A., Laliberte, A.S., Scott, R.L.: High-resolution characterization of a semiarid watershed: Implications on evapotranspiration estimates, J. Hydrol., 509, 306-319, doi:10.1016/j.jhydrol.2013.11.047, 2014.

75. Toté, C., Patricio, D., Boogaard, H.L., Wijngaart, R. van der, Tarnavsky, E., and Funk, C.: Evaluation of Satellite Rainfall Estimates for Drought and Flood Monitoring in Mozambique, Remote Sens., 7, 1758-1776, doi:10.3390/rs70201758, 2015.

76. Trambauer, P., Dutra, E., Maskey, S., Werner, M., Pappenberger, F., van Beek, L. P. H., and Uhlenbrook, S.: Comparison of different evaporation estimates over the African continent, Hydrol. Earth Syst. Sci., 18, 193-212, doi:10.5194/hess-18193-2014, 2014.

77. Tyagi, N.K., Sharma, D.K., and Luthra, S.K.: Determination of evapotranspiration and crop coefficients of rice and sunflower with lysimeter. Agric. Water Manage., 45, 41-54, doi: 10.1016/S0378-3774(99)00071-2, 2000. 
Hydrol. Earth Syst. Sci. Discuss., https://doi.org/10.5194/hess-2017-251

Manuscript under review for journal Hydrol. Earth Syst. Sci.

Discussion started: 6 June 2017

(c) Author(s) 2017. CC BY 3.0 License.

(c) (1)
Hydrology and

Earth System

Sciences

Discussions

78. van Griensven, A., Meixner, T., Grunwald, S., Bishop, T., Diluzio, M., and Srinivasan, R.: A global sensitivity analysis tool for the parameters of multi-variable catchment models, J. Hydrol., 324, 10-23, doi:10.1016/j.jhydrol.2005.09.008, 2006.

79. van Griensven, A., Ndomba, P., Yalew, S., and Kilonzo, F.: Critical review of SWAT applications in the upper Nile basin countries, Hydrol. Earth Syst. Sci., 16, 3371-3381, doi:10.5194/hess-16-3371-2012, 2012

80. van Griensven, A., Maskey, S., and Stefanova, A.: The use of satellite images for evaluating a SWAT model: Application on the Vit Basin, Bulgaria, in R. Seppelt, A.A. Voinov, S. Lange, D. Bankamp (Eds.): International Environmental Modelling and Software Society (iEMSs) International Congress on Environmental Modelling and Software: Managing Resources of a Limited Planet: Pathways and Visions under Uncertainty, Sixth Biennial Meeting, Leipzig, Germany, 3030-3037, ISBN: 978-88-9035-742-8, 2012.

81. Vardon, M., Lenzen, M., Peevor, S., and Creaser, M.: Water accounting in Australia, Ecol. Econ., 61, 650-659, doi:10.1016/j.ecolecon.2006.07.033, 2007.

82. Vazifedoust, M., van Dam, J.C., Feddes, R.A., and Feizi, M.: Increasing water productivity of irrigated crops under limited water supply at field scale, Agric. Water Manage., 95, 89-102, doi:10.1016/j.agwat.2007.09.007, 2008.

15 83. Vigorstol, K. L. and Aukema, J. E.: A comparison of tools for modeling freshwater ecosystem services, J. Environ. Manage., 92, 2403-2409, doi:10.1016/j.jenvman.2011.06.040, 2011.

84. Villa, F., Athanasiadis, I.N., and Rizzoli, A.E.: Modelling with knowledge: a review of emerging semantic approaches to environmental modelling, Environ. Model. Softw., 24, 577-587, doi:10.1016/j.envsoft.2008.09.009, 2009.

85. Vu, H. S., Watanabe, H., and Takagi, K.: Application of FAO-56 for evaluating evapotranspiration in simulation of pollutant runoff from paddy rice field in Japan. Agric. Water Manage., 76, 195-210, doi:10.1016/j.agwat.2005.01.012, 2005.

86. Wang-Erlandsson, L., Bastiaanssen, W.G.M., Gao, H., Jägermeyr, J., Senay, G.B., van Dijk, A.I.J.M., Guerschman, J.P., Keys, P.W., Gordon, L.J., and Savenije, H.H.G.: Global root zone storage capacity from satellite-based evaporation, Hydrol. Earth Syst. Sci., 20, 1459-1481, doi:10.5194/hess-20-1459-2016, 2016. 